\title{
Application of DPSIR Model to Identify the Drivers and Impacts of Land Use and Land Cover Changes and Climate Change on Land, Water and Livelihoods in the L. Kyoga Basin: Implications for Sustainable Management
}

John Peter Obubu ( $\triangle$ peterobubu@gmail.com )

Addis Ababa University https://orcid.org/0000-0003-2159-7398

Robinson Odong

Makerere University

Tena Alamirew

Ethiopian Institute of Water Resources

\section{Tadesse Fetahi}

Addis Ababa University

Seyoum Mengistou

Addis Ababa University

\section{Research Article}

Keywords: Drivers, communities, forests, wetlands, fertilizers, impacts, population

Posted Date: February 7th, 2022

DOI: https://doi.org/10.21203/rs.3.rs-1246419/v1

License: (c) (i) This work is licensed under a Creative Commons Attribution 4.0 International License.

Read Full License 


\section{Abstract \\ Background}

Land use, land cover, and climate change impacts are current global challenges that are affecting many sectors, like agricultural production, socioeconomic development, water quality, and causing land fragmentation. In developing countries like Uganda, rural areas with high populations that are dependent on agriculture, are the most affected. The development of sustainable management measures requires proper identification of drivers and impacts on the environment and livelihoods of the affected communities. This study applied drivers, pressure, state, impact, and response model in the L. Kyoga basin to determine the drivers and impacts of land use, land cover, and climate change on livelihoods and the environment. The objective of this study was to determine the drivers and impacts of land use, land cover, and climate changes on the environment and livelihoods in the L. Kyoga basin, and suggest sustainable mitigation measures. Focus group discussions, key informant interviews, field observations, and literature reviews were used to collect data.

\section{Results}

Population increase and climate change were the leading drivers, while agriculture and urbanization were the primary pressures, leading to degraded land, wetlands, and forests; loss of soil fertility, hunger, poverty, poor water quality, which are getting worse. The local communities, government, and nongovernment institutions had responses to impacts, which included the use of agrochemicals, restoration, and conservation approaches. Most responses had promising results, although they were at a small/pilot scale level. It was also found that the application of policies and regulations to manage impacts was weak.

\section{Conclusion}

Land use, land cover changes, and climate change are taking place in the L. Kyoga basin with major impacts on land, water, and community livelihoods. With the observed increase in climate change and population growth, there is a potential of drivers and impacts getting worse. It is therefore important to expand interventions, provide relief, review policies and regulations, and enforce them. The findings are useful for decisions and policymakers to design appropriate management options.

\subsection{Introduction}

Land use and land cover (LULC) change and climate change (CC) have become synonymous with contemporary discussions globally, as they are intertwined and are impacting many aspects of livelihoods and socio-economic developments (IPCC 2007; Wan et al., 2014; Amjath-Babu et al., 2016). Whereas land cover (LC) includes the natural physical features of the land in addition to man-made 
structures that form the landscape, land use (LU), covers the way humans utilize land and its associated resources (Alemayehu et al., 2009). On the other hand, climate change refers to the human-induced change in climate that varies the configuration of the global atmosphere and adds to natural variability experienced over similar time scales (UNFCCC 2011). There are many drivers of LULC and CC at the international level, and they are divided into two main categories, i.e., proximate and underlying (Bisaro et al., 2014; Pingali et al 2014; Belay et al., 2015). The proximate drivers with direct impacts on watersheds include natural phenomena associated with climate, droughts, topography, deforestation, agriculture, and wildfires (Dregne 2002; Lambin and Geist 2008). The underlying drivers, with indirect consequences, include population density, poverty, the land tenure system, and weakly implemented regulations and policies (Tiffen et al., 1994; Kabubo-Mariara 2007; Gessessew 2017). Whereas emission of greenhouse gasses, especially by developed countries is regarded as the primary driver of CC, population increase in less developed countries, is considered the main underlying driver of LULC change, (Farauta et al., 2012; Bone et al., 2017; Gondwe et al., 2019). Population increase alone might not lead to LULC change, especially in the developed countries, with diverse sources of livelihoods; it is only an issue in developing countries where the people are dependent on natural resources with less advanced agricultural technologies (Nkonya et al., 2008). Other drivers are economic and technological developments (Turner et al., 1995), and urbanization (Alemayehu et al., 2009). The desire to satisfy the insatiable human needs for a better life has impacted the environment, water, and livelihoods in different ways (Agarwal et al., 2000; Rawat and Manish 2015). Hence, LULC change and CC are set to be reoccurring without abatement unless drastic actions are taken (Mustard et al., 2005).

There is a synergetic relationship between LULC changes and CC with other factors causing impacts in our environment (Agyemang 2012; Vu et al., 2014). Whereas LULC change can lead to loss of soils and nutrients from poor agricultural activities (Fatumah et al 2020), it is the CC that is responsible for transporting the sediments and nutrients to the receiving water bodies through river/stream flows, run-off, and shallow groundwater (Urama and Zor 2010; Huong and Pathirana 2013). LULC changes and CC have been studied at global, regional, and national levels. But to properly understand the drivers and impacts of these changes on livelihoods, land, and water, study at the local level is essential. This is important since the understanding of human-nature interactions requires explicit local knowledge and involvement of the local communities (Bremner et al., 2010).

Different ways have been used to identify LULC changes, including the use of geographical information systems (GIS) and remote sensing using satellite data (Sun et al., 2013; Bu et al., 2014). However, the use of the Driver, Pressure, State, Impact and State (DPSIR) model to link socio-economic growth effects on the environment (Kelble et al., 2013) has also gained popularity. It effectively describes the cause-effect associations between human-led development sectors and the environment (Pinto et al., 2013; Hou et al., 2014) and links between its component elements (Dzoga et al., 2020). For example, the relation between the 'impacts' of a change of ecosystem or humans and the 'state' of the ecosystem depends on the system's threshold and carrying capacity (Kristensen 2004). The model's credibility is on its ability to serialize human effects on the environment, from drivers to the responses (Sun et al., 2016), and for establishing information on the status of the environment (Elliott 2002). Thus, it is an essential tool for 
decision-makers, policy-makers, water and land managers, and the general public for effective and sustainable management (Timmerman et al., 2011; Sekovski et al., 2012), at regional and local levels (Kelble et al., 2013; Sun et al., 2016). It has been applied in different circumstances, for example, support to support fish and fisheries management in Lake Tana, Ethiopia (Gebremedhin et al., 2018); and to interpret the rate of siltation of water reservoirs in Mexico (Porta and Posh 2011). Unlike the remote sensing approach, the model allows researchers to interact with communities, identifying local drivers, pressures, states, impacts, and responses/coping mechanisms. Therefore, it provides a platform where local community knowledge can be incorporated into the scientific aspects of particular natural resources, bridging the gap between science and management and policy developments/reviews (Gebremedhin et al., 2018). Despite the value of information that the DPSIR model generates, useful for management and decision making, developed countries have applied it more (Gabrielsen and Bosch 2003; OECD 2003, Martins et al., 2012) than developing ones, especially those in Africa where most published papers are reviews (Agyemang et al., 2007; Gessesew 2017; Gebremedhin et al., 2018), including Uganda.

The objective of this study was to use the DPSIR model to identify drivers, and impacts of both LULC change and $\mathrm{CC}$ on the environment, water, and livelihoods in the L. Kyoga basin, using indigenous knowledge and stakeholder interactions. The research used focused group discussions (FGDs) and key informant interviews (KIIs) with the local community members, stakeholders, and field observations to identify these drivers and impacts, and coping mechanisms. The outcome of this research is the development of holistic and efficient LULC change and CC management approaches that are "bottomup", i.e., from communities to government policy and decision-makers. This is in contrast to most cases, where decision-makers prefer less consultative and often counterproductive "top-down" approaches in dealing with LULC change and CC impacts. The findings are also applicable in the monitoring and implementation of United Nations Sustainable Development Goals (SDGs) in Uganda, which advocate on poverty reduction (Goal 1), maintenance of clean water quality and sanitation (Goal 6), and taking corrective action on climate (Goal 13) by 2030.

\subsection{Materials And Methods}

\subsection{Study area}

The study area is located in eastern Uganda, north of L. Victoria, with coordinates $0^{\circ} 24.50^{\prime} \mathrm{N}-2^{\circ} 25.50^{\prime} \mathrm{N}$; $32^{\circ} 5^{\prime} 10^{\prime} \mathrm{E}-34^{\circ} 46^{\prime} 30^{\prime} \mathrm{E}$, and covers three catchments, including Awoja, Mpologoma, and Lwere, (Figure 1). These catchments cover a more significant part of the eastern catchments of L. Kyoga, which is a recipient of the water from these catchments. Lwere is the smallest of these catchments, with an area of $1,500 \mathrm{~km}^{2}$; Mpologoma is the second largest in the basin with an area of $9,000 \mathrm{~km}^{2}$, with 13 subcatchments (MWE 2018). Awoja is the most extensive catchment of the basin, with an area of 11,000 $\mathrm{km}^{2}$ and 14 sub-catchments (MWE 2015). The study area covers 34 of the total 58 districts of the L. Kyoga basin. Its population estimate is 9.4 million people, with the youth below 30 years constituting over 
$75 \%$ of this population (UNBS 2020). The study area has Mt Elgon, which is 4,321 meters above sea level (m.a.s.I), at the border between Uganda and Kenya. This mountain is the source of rivers and streams that drain the catchment and is also a settlement, agricultural, and forestry area, hence playing a major role in LULC changes and CC. This mountain together with lakes in the area, like Kyoga and Victoria, are the leading influencers of the climate of the study area (Camberlin 2009; MWE 2018). The two phenomena of LULC change and CC are the most critical factors that affect this basin with impacts on livelihoods and the environment.

The study area was divided into three segments, including (1) the upstream which covered the top and slopes of mountains Elgon and Kadam, the districts here included Kapchorwa, Nakapiripirit, Bududa, Bukwo, and Kween (2) the mid-stream, which included the lower slopes of Mt. Elgon and the higher grounds, districts covered here included Mbale, and Kumi, Butebo; and (3) the downstream, which included the flood plains of Teso and parts of Busoga. Districts here included Serere, Pallisa, Ngora Butaleja, Buyende. Upstream districts experience erosion due to the steep nature of the land, with bare land as a result. Mid-stream areas were observed with lush wetlands as a result of nutrient and sediment deposition from the upstream, resulting in fertile agricultural soils. The downstream areas had extensive wetlands, as the river flow slowed down before discharging water into L. Kyoga. Further deposition of sediments occurs here, making soils and wetlands nutrient-rich, hence they are highly cultivated and degraded. This diminishes the ecological buffering role of wetlands, including the uptake and storage of excess nutrients and filtering sediments.

The topographical division influences the state and impacts of LULC change and CC under the same drivers. The study area also had two distinct climatic zones; the drier northern cattle corridors of Karamoja and parts of Teso, which receive less rainfall, and the Mt. Elgon area, which receives high amounts of rainfall, making the region vulnerable to impacts of CC and LULC change (Mboga 2012; MWE 2013). The main LULC activities in the study area include conversion of land, forests, and wetlands into agriculture, mainly for rice fields, and also human settlement, and urbanization. Further, sand mining, quarrying for marram, and artisanal mining of minerals, such as limestone, take place in the area. The LULC changes, alongside CC impacts, primarily result in floods, land, and mudslides, as well as droughts, adversely affecting the environment, water, and livelihoods over time.

\subsection{Data collection and analysis}

\subsubsection{Data collection}

Data collection was done using three principal approaches: focus group discussions (FGDs), key informant interviews (KIls), and field observations. The FGDs is a key that was first developed in the 1920s (Morgan 1998), formalized in the 1940s (Madriz 2000), and has been refined and widely used by various scientists for qualitative data collection (Onwegbuzie et al., 2009; Nyumba et al., 2018). The data collection was done in representative districts in the upstream, midstream, and downstream areas to capture the perceptions and views from all the study areas. Focus groups consisted of a minimum of 12 and a maximum of 15 members, although in Kumi district, there were 21 members. Fifteen members for 
each FGD have been recommended and used by many authors, to allow members to express themselves (Onwegbuzie et al., 2009; Makwinja et al., 2021), but at the time of this study, it allowed FGDs to follow standard operation procedures (SOPs) against Covid-19 pandemic, which included social distancing and wearing of facemasks (Figure 2).

The FGDs and KIls took a maximum of one and a half hours and were moderated by two people, the researcher, and a well-trained assistant, to ensure consistency, as recommended by Maxwell et al., (2012). There were nine FGDs, and thirteen KIls carried out in the study area. That number was reached as information saturation was attained, following Sandelowski (2008). The FGDs were organized with the help of the Ministry of Water and Environment (MWE) deconcentrated regional office, Kyoga Water Management Zone (KWMZ), in conjunction with district community development officers (DCDOs). Openended questions on the drivers, pressures, states, impacts, and responses to LULC changes and CC were administered. The drivers and impacts were ranked by the participants according to the Linkert scale, from 1-5 ( 1 = most important, and 5 = least important). Klls followed a phenomenological tactic as described by Patton (1990). The KIs were elderly, above 55 years of age, and residents of the study area. Others were experienced office bearers rendering service to the community, from government and nongovernment agencies. The independent data and information from Kls were used to validate the information from the FGDs. All FGDs and KIls strictly followed ethical guidelines recommended for data collection (Levy and Lemeshow 2013).

Field observations by the researcher during the time of data collection were also used to collect the current information on the drivers and impacts of LULC changes and CC in the study area. Here, the state of wetland degradation and conversion into rice fields was observed, and forest degradation, among others, was observed firsthand during data collection.

Literature reviews were also carried out to obtain relevant data and information for the study. For example, the Uganda Bureau of Statistics (UBOS, www.ubos.org), accessed on the 25th May 2021) was visited to obtain accurate and projected population data. Secondary data on the river discharges, water levels, and water quality for Mpologoma, Awoja rivers, and L. Kyoga were obtained from MWE.

\subsection{Data Analyses}

FGD and KII data were analyzed through coding and organization into thematic groups for easy presentation. This was done following the constant comparison analysis approach (Onwegbuzie et al., 2009), which was first developed by Glaser and Strauss (1968). Data were then grouped into drivers, pressures, state impact, and responses. Water discharge data, water level, and water quality data were analyzed in Excel and graphs and developed into tables.

\subsection{Results}

The summary of the results which were obtained from the FGDs and KII is presented in the DPSIR conceptual framework model (Figure 3). 


\subsection{Discussion}

\subsection{Drivers (D) of land use, land cover, and climate change}

Drivers are essential societal needs like food, shelter, energy, and transport that have to be met regularly, and are in two categories, namely proximate (Dregne 2002; Lambin and Geist 2008) and underlying (Tiffen et al., 1994; Kabubo-Mariara 2007). The requirements for meeting these needs vary from one country to another and from urban to rural settings. In the less developed countries, like Uganda, especially in rural settings, the immediate needs are met mainly by using natural resources (Reynolds et al., 2007; Bremner et al., 2010). During data collection, six significant drivers were identified by the local communities. These included population increase (Figure 3), climate change, economic development, politics, low education levels, and land tenure.

The population increase was identified as a number one driver in eight of the nine FGDs carried out, except in Nakapiripirit (Karamoja region), where low education levels/high illiteracy rates ranked highest. Population pressure has impacted land, wetlands, and forests, which have been degraded to meet the essential human needs, primarily through agriculture. UBOS data indicates the study area as one of the most populated regions in the country (UBOS, 2020) as shown in figure 4.

Whereas high population impacts LULC change and CC, the youthful population structure in Uganda and in the study area in particular, where up to $78 \%$ of the population is below 30 years of age, is worrying. Uganda's average population density is estimated at $228 / \mathrm{Km}^{2}$, with a growth rate of $3.32 \%$ and a fertility rate of 4.78 births per woman, hence ranking among the highest globally UBOS (2020). Such population growth rate is associated with rapid urbanization and high poverty levels observed in the study area. With an unemployment rate of over $2.9 \%$, which is higher than the national rate of 2.44 , this population is now heavily dependent on natural resources as sources of income or doing petty jobs in the urban centers. Therefore, the young, energetic population, dependent on parents, has become a real burden to the natural resources, as they are being used as human labor to degrade natural resources, which in turn has resulted in CC, as has been observed by other studies (Reynolds et al., 2007; de Sherbinin et al., 2008; Alemayehu et al., 2009; Bremner et al., 2010; Akhtar et al., 2011; Kirui and Mirzabaev 2015; Ashfaq et al., 2019).

Population-related drivers also act synergistically with other community aspects, like poverty, socioeconomics, and environmental factors, causing LULC change and CC. Poverty, an underlying driver, in synergy with other factors was the second driver of LULC changes and CC, as poor people depend on natural resources, as pointed out by other authors in Kenya (Kirui et al 2015), the USA (Bremner et al., 2010) and Germany, (Biraso et al 2014). National poverty indices showed Eastern alongside the Northern regions as one of the poorest in Uganda (UBOS 2020; UNICEF 2020).

The need for shelters, energy in the form of firewood and charcoal and hunger, low education levels, weak law enforcement, urbanization for alternative income, lack of cash crops, loss of cultural values, and high 
cost of land were other drivers of LULC change and CC; all these factors are related to the high youthful population. This agrees with what was found by other authors (Lambin et al., 2001; Geist and Lambin 2002; Harte 2007). In Nakapiripirit and Karamoja areas, low education level, hence high illiteracy, was the number one driver. Production of domestic and industrial effluents from Karamoja mineral mining, and domestic effluents from urban centers, including Mbale, Soroti cities, Iganga, and Tororo municipalities, impacted the land and water resources, as pointed out by other studies (Kristensen 2004; Anaba et al., 2016). Climate change was also identified as one of the significant drivers of LULC changes in the study area. This was in agreement with the findings of $\mathrm{CC}$ in the study area, reported in the related study (Obubu et al., 2021). Deforestation and wetland degradation, aggravated by high population, lead to CC; meanwhile, CC leads to forest and wetland loss, a vicious cycle that is observed globally (Bremner et al., 2010 Nkonya et al., 2011; Biraso et al., 2014). Political interference was cited as one of the drivers of LULC changes, especially in wetland and forest degradation. This was cited in Pallisa, Kibuku, Kumi, and other districts, where politicians would urge their constituents to defy regulations and encroach on wetlands and forests for political gain, especially during elections. Limoto wetland, located between Pallisa and Kibuku, is an example where political interference seriously compromised conservation activities.

Land tenure systems were also pointed out as drivers of LULC change and CC. There were four types of land tenure systems in the study area: customary ownership; which was the most dominant type, community; leasehold in urban centers; and cultural land ownerships. Customary tenure was identified as a driver of LULC change as parents have to keep on sub-dividing the finite land to the infinite number of children. This would result in land fragmentation and conflicts between families. This study revealed that, in Bududa, the amount of land a son inherits is dependent on how well-behaved his wife is to the parentsin-law. The participants noted the difficulty in commercializing customary, communal, and cultural lands without the parents' permission, community and cultural leaders, and the result was land fragmentation for agriculture and settlement. In Nakapiripirit, the communities accused the local government leaders of taking advantage of communal land tenure by selling and leasing it to commercial developers like companies and academic institutions without consulting them, thus changing LU's purpose. Acerer village and Nakapiripirit town council were cited as examples where such abuse of land tenure systems was rampant. These findings agree with what was found in Kenya by Kakubo-Mariana (2007) where issues of land rights and land conservation were discussed.

\subsection{Pressures of land use, land cover changes, and climate change}

The need to meet the drivers of LULC change and CC results in exploiting natural resources; these exploitative activities place pressure on the environment (land and water) (Kelble et al., 2013). The pressures were grouped into thematic areas, with agriculture, urbanization, and economic development identified and leading pressures (Figure 3). Many people are entirely dependent on agriculture, just like it is the mainstay in the country, where it supports over $70 \%$ of the local economy (Ojara et al., 2020). Although maize, sorghum, rice, and millet were cultivated across the study area, Arabica coffee was 
unique to the mid and upstream districts on Mt. Elgon like Mbale, Bududa, Kapchorwa, as the weather here and high altitudes above 1,600 m.a.s.I favors it (MWE 2015). Cassava was dominant in the downstream districts of Serere, Kumi, and Palissa. The demand for food resulted in the conversion of wetlands, riverbanks, I, and forests into agricultural lands as observed in Limoto wetland in Palissa, a situation observed in Kampala, Uganda (Matagi 2002), in Kenya, Malawi, and Tanzania (Kirui et al., 2015). There was also reported cultivation on the steep slopes of Mt. Elgon with minimum terracing, a practice that has resulted in the mud and landslides during rainy seasons, with many damages to infrastructure and deaths almost on an annual basis as was also pointed out by Dregne (2002).

Boosting agricultural production to meet food demands is now supported by applying agrochemicals, as reported by the participants (Table 1). These included fertilizers, herbicides, and pesticides. The participants emphasized that, without their use, the farmers get poor and low yields. Other reasons for using these chemicals included loss of soil fertility, losses due to pests and diseases, and CC. It was only in Nakapiripirit, where agrochemicals were not being used yet, due to land availability, small population, good soil fertility, and nomadic lifestyle.

Table 1

Agricultural chemicals used in L. Kyoga Basin

\begin{tabular}{|llll|}
\hline SN & Fertilizers for agriculture & Pesticides trade name & Herbicides trade name \\
\hline 1 & $\begin{array}{l}\text { Nitrogen, phosphorus, and potassium } \\
\text { (NPK) based e.g., Sukulu }\end{array}$ & Super grow & $\begin{array}{l}\text { Roundup contains } \\
\text { glyphosate }\end{array}$ \\
\hline 3 & Organic/Manure & Dudu cipher & $\begin{array}{l}\text { Weed master contains } \\
\text { glyphosate }\end{array}$ \\
\hline 4 & Diammonium phosphate (DAP) & Rocket & $\begin{array}{l}2-4 \\
\text { Dichlorophenoxyacetic } \\
\text { acid (2-4-D) }\end{array}$ \\
\hline 5 & Calcium ammonium nitrate (CAN) & Striker & Tafgor/dimethoate \\
\hline 6 & Vegimax (Organic-NPK) & $\begin{array}{l}\text { Force up, contains } \\
\text { glyphosate }\end{array}$ \\
\hline 7 & Evergreen & Ambush & Ametrine \\
\hline 8 & Allwin gold super & Dudumaki & \\
\hline 9 & Rhizobium (biological fertilizer) & Golden drop, an organo- & \\
\hline 10 & Digrow (Organic Plus foliar fertilizer) & Silicon based & \\
\hline 11 & Aminocop & & \\
\hline 12 & TAP Triamide phosphoryl & & \\
\hline
\end{tabular}


The communities started using these chemicals at varied times; the upstream districts over 30 years ago, while the downstream districts started as recently as five years ago. This confirmed the argument that upstream districts lost fertility earlier due to soil erosion, while the downstream district had fertile soils due to deposition of nutrients and sediments from upstream districts. Land fragmentation has affected most parts of the study area as shown by the widespread use of agrochemicals, except in Nakapiripirit. This was confirmed by the Kls, who indicated that the land was in plenty and fertile in the past 30-40 years. Fallowing eliminated the need for the use of agrochemicals. These agrochemicals affect soils, but especially the water quality of the receiving water resources, like rivers Awoja and Mpologoma and L. Kyoga, through run-off, facilitated by CC (Obubu et al., 2021). Similar observations were also made in Qatar and Ethiopia (Akhtar et al., 2011; Gebremedhin et al., 2018).

Urban centers have put pressure on land as agricultural land, forests, and in some cases, wetlands have been converted into urban centers, like Imatakojo forest in Pallisa district, which was converted into an urban center, as has also been observed in other areas (McKinney 2002; Tang et al., 2005; Akhfar et al., 2011; Rawat and Kumar 2015; Gebremedhin et al., 2018). Forests have been degraded to provide timber for construction and energy in form of charcoal and firewood. Meanwhile, domestic wastes from these centers are also sources of contamination of land and water resources. Sewerage effluent data from Soroti and Mbale cities and Tororo and Iganga municipalities were obtained from the MWE from 2014 to 2021. The mean annual values for Electrical conductivity (EC), pH range, Total Suspended Solids (TSS), Total Phosphorus (TP), Total Nitrogen (TN), and Biochemical Oxygen Demand (BOD) were compared with the National Environment (Standards for discharge of effluent into water or land) Regulations 2020, (Table 2). 
Table 2

Domestic effluents against wastewater discharge standards

\begin{tabular}{|llllllll|}
\hline Year & $\begin{array}{l}\mathrm{EC} \\
(\mu \mathrm{S} / \mathrm{cm})\end{array}$ & $\begin{array}{l}\mathrm{pH}(\mathrm{pH} \\
\mathrm{units})\end{array}$ & $\begin{array}{l}\mathrm{TSS} \\
(\mathrm{mg} / \mathrm{l})\end{array}$ & $\begin{array}{l}\mathrm{TP} \\
(\mathrm{mg} / \mathrm{l})\end{array}$ & $\begin{array}{l}\mathrm{TN} \\
(\mathrm{mg} / \mathrm{l})\end{array}$ & $\begin{array}{l}\text { BOD } \\
(\mathrm{mg} / \mathrm{l})\end{array}$ & $\begin{array}{l}\mathrm{COD} \\
(\mathrm{mg} / \mathrm{l})\end{array}$ \\
\hline 2014 & 884 & $8.0-10.0$ & & 3.16 & & 35 & 231 \\
\hline 2015 & 612 & $7.1-9.2$ & 75 & & & 12 & 144 \\
\hline 2016 & 1039 & $6.8-9.4$ & 136 & 3.6 & & 187 & 1438 \\
\hline 2017 & 837 & $6.8-8.6$ & 210 & & & 18 & 152 \\
\hline 2018 & 1098 & $6.9-9.1$ & & & 75.7 & 7 & 264 \\
\hline 2020 & & $6.8-9.9$ & & & & 69 & 156 \\
\hline 2021 & 1059 & $5.3-11.0$ & 309 & 7.9 & 52.8 & 26 & 366 \\
\hline Effluent & 750 & $5.0-8.5$ & 50 & 5 & 10 & 50 & 70 \\
\hline
\end{tabular}

All the parameters were at least above the standards in different years, putting pressure on the water quality of L. Kyoga and land. The EC met the standards in 2016, and pH tended to alkalinity in all the years. TSS, COD, and TN did not meet the standards; BOD in two years (2016 and 2020) out of the seven years did not meet the standards, the result is the pollution of water resources and land. According to local communities, other economic activities in the study area that exerted pressure on natural resources were the development of agro-processing industries like distilleries, where raw hot waste was released into the environment without treatment, affecting receiving water ecosystems such as River Nakibiso in Mbale district. As a result, parts of the river had been seriously contaminated, rendering the water unfit for any use. The participants in Nakapiripirit district also reported pollution from artisanal mining activities of minerals like gold. Meanwhile, most industries in Mbale and Tororo districts were found to operate dry processes, hence the need to monitor gaseous emissions and their effects on the atmosphere and CC, which was not done in the study.

\subsection{State of land use, land cover change, and climate change}

Given that drivers are the human needs, and pressures are the activities carried out using the natural resources to satisfy the needs, the transformation of natural resources, hence the loss of quality ecosystem services they provide, represents the state of particular natural resources. (Kristensen 2004, Gessesew 2017). 


\subsubsection{State of water and environment}

Participants ranked land, wetlands, forests, and riverbanks as the most degraded land uses, especially for agriculture. Soil erosion, bare land, and formation of gullies, especially in the upstream districts at the slopes of Mt. Elgon, but also in Pallisa was reported. Protected areas are getting degraded by displaced people as the population keeps increasing. There was also a reported increase in pests and diseases, although this could not be independently verified due to a shortage of data. One of the salient issues discovered by this research was the conversion of the most revered cultural land/sites into agriculture, especially in Pallisa, Bududa, and Nakapiripirit districts. Some of these cultural sites included Nashinda, Nashoba, Yerakha, Namasho, Nameremu, and Nehoyo in Bududa, which were hitherto protected by the communities. Up to 30 years ago, they were sites of sacrifices and celebrations during catastrophes and in plenty respectively. Indirectly, they became bushy and forested, thus refugia for biodiversity (wild animals and birds), a situation reported in Burkina Faso, Benin, and Togo in Weste Africa (Juhe-Beaulaton 2006; Kokou and Sokpon 2006). Some elderly participants and Kls associated the current droughts, floods, and diseases with the encroachment to these sites as they believe the "gods are annoyed." Government and other stakeholders should take advantage of these cultural values and beliefs and integrate them into conservation policies and laws to protect the environment and natural resources in the study area and beyond.

Field observations during data collection also confirmed the degradation of natural wetlands through rice growing (Figure 5). These findings agree with the work done in the Namataba wetland, (Namaalwa et al., 2013) and Naigombwa wetland (Were et al., 2020), which are parts of this study area.

Meanwhile, the National Water and Sewerage Corporation (NWSC), the water supply agency for Mbale City, reported increased siltation, sedimentation, and coloration of water in River Manafwa, an intake point, during wet seasons, due to soil erosion, especially from artisanal sand and iron mining in the upstream areas (Table 3).

Table 3: Seasonal variation of water quality in R. Manafwa (intake for Mbale water supply)

\begin{tabular}{llllll} 
Season & $\mathrm{pH}$ & $\mathrm{EC}(\mu \mathrm{S} / \mathrm{cm})$ & Turbidity $(\mathrm{NTU})$ & Colour-app (PtCo) & TSS $(\mathrm{mg} / \mathrm{l})$ \\
\hline Wet & 7.1 & 113 & 1,348 & 10,843 & 1,900 \\
\hline Dry & 7.2 & 171 & 475 & 5,179 & 774
\end{tabular}

Data source: NWSC, Mbale district

There was a distinct variation in water quality parameters in wet seasons (March-May) and dry seasons (June to August), with the management reporting an increase in the quantities of water treatment chemicals, hence potentially increasing the cost of water supplied to consumers (Table 4). Indeed, some participants in this area reported that tap water supplied by NWSC was often brownish, especially during heavy rainy seasons. 
Table 4

Seasonal variations in water treatments cost

\begin{tabular}{|c|c|c|c|c|c|c|c|}
\hline season & Chemical & $\begin{array}{l}\text { dosage } \\
(\mathrm{mg} / \mathrm{l})\end{array}$ & $\begin{array}{l}\text { Weight } \\
\text { (Kgs) }\end{array}$ & $\begin{array}{l}\text { Raw } \\
\text { water } \mathrm{m}^{3}\end{array}$ & $\begin{array}{l}\text { Amount/Kg } \\
\text { (UGX) }\end{array}$ & $\begin{array}{l}\text { Total } \\
\text { amount }\end{array}$ & $\begin{array}{l}\text { Amount } \\
\text { in (UDS) }\end{array}$ \\
\hline \multirow[t]{3}{*}{ Wet } & Chlorine & 2.050 & 546 & 300,000 & 15,000 & $8,190,000$ & 2,307 \\
\hline & Alum & 70.000 & 12,320 & 300,000 & 1,200 & $14,784,000$ & 4,165 \\
\hline & Polymer & 15.000 & 1,651 & 300,000 & 5,000 & $8,255,000$ & 2,325 \\
\hline $\begin{array}{l}\text { Sub- } \\
\text { total }\end{array}$ & & & & & & $31,229,000$ & 8,797 \\
\hline \multirow[t]{3}{*}{ Dry } & Chlorine & 1.803 & 485 & 300,000 & 15,000 & $7,275,000$ & 2,049 \\
\hline & Alum & 25.378 & 6,988 & 300,000 & 1,200 & $8,385,600$ & 2,362 \\
\hline & Polymer & 2.388 & 714 & 300,000 & 5,000 & $3,570,000$ & 1,006 \\
\hline $\begin{array}{l}\text { Sub- } \\
\text { total }\end{array}$ & & & & & & $19,230,600$ & 5,417 \\
\hline Total & & & & & & $50,459,600$ & 14,214 \\
\hline
\end{tabular}

There was also reported loss of biodiversity, especially wild animals like leopards, antelopes, baboons, and wild birds like eagles that dwelt in wetlands, forests, and woodlands, due to clearance of their habitats. These were pointed out by the KIs, who were knowledgeable about these animals before they disappeared.

\subsubsection{State of livelihoods in the study area}

There is a growing number of internally displaced people by floods, land, and mudslides, especially from Bududa district located at the slopes of Mt. Elgon. These people are relocated into camps in protected areas, in Kiryadongo with over 500 people and Bulambuli with over 600 people. These people lack some of the basic needs, including sanitation, food, and water supply for domestic purposes. There was also reported damage to homes and infrastructure including, roads and water supply lines, affecting livelihoods. This shows that CC is acting synergistically with LULC changes, exacerbating the damage to the environment and negatively impacting human livelihoods through poor sanitation, shortage of food, and shelter. Further, participants, especially in the downstream districts of Serere, Kumi, and Palissa, the traditional cattle-keeping communities, reported a reduction in domestic animals due to a shortage of grazing land.

\subsection{Impacts of LULC change and CC on the environment, water, and livelihoods}




\subsubsection{Impacts on land}

Loss of soil fertility was reported across the study area as a number one impact of LULC change and CC. The participants reported low harvests now compared to what they used to get from the same acreages of land 30 years ago. They are reported poor quality of crop and animal yields, as a result of low soil fertility, which agrees with findings by Osbahr et al., (2011) in Mbarara district, western Uganda. The local communities noted that soil erosion had eroded the topsoil, especially in the steep slopes of Mt. Elgon, leaving infertile underground soil, which agrees with what was reported by other authors (Alemeyehu et al., 2009; Porta and Claret 2011; Anaba et al., 2017). Expect in Nakapiripirit where land is still fertile, the rest of the study are reported increased application of agrochemicals to boost agricultural production, which is in line with a study by Akhtar et al., (2011).

The land resources have been degraded and no longer support the population; hence the local communities are encroaching on protected lands, like forests and wetlands, for crop production. The clearance of forests and degradation of wetlands has resulted in erratic precipitation and droughts (climate change), and the vicious cycle is getting worse every year, as also reported by Bremner et al., (2010) and Obubu et al., (2021). At the national level, forest coverage has reduced from $24 \%$ in the 1990 s to $12.4 \%$ in 2020 (MWE 2020). Relatedly, wetland coverage has reduced from $15.6 \%$ in 1994 to $8.9 \%$ in 2020 (MWE 2020). The conversion to agricultural land is the main LULC change, as reported in the tropics (Geist and Labin 2002). There was also reported loss of biodiversity in forests and wetlands. Further, the poor-quality crops and animals are more vulnerable to infestation by pests and diseases, with participants reporting an increased outbreak of pests and diseases exacerbated by CC; this was also observed by Hisali et al., (2011). These observations were proved by the increasing use of pesticides over the last five years generally and over 30 years in the upstream district which experienced the loss of soil fertility earlier due to soil erosion as a result of steep terrain. There were also reported increased costs incurred by the respective local government authorities and members of communities in the maintenance, repair, and replacement of damaged infrastructure and facilities, including roads, homes, health centers, and schools.

\subsubsection{Impacts of LULC change and climate change on livelihoods}

There were displacements from land and mudslides and deaths in different communities. A total of 427 people were reportedly killed by floods, land, and mudslides in the recent past (Table 5). 
Table 5

Recent deaths from floods, land, and mudslides in the study area

\begin{tabular}{|llll|}
\hline District & Sub-counties & year & No. of deaths \\
\hline Bududa & Bundesi & 2010 & 300 \\
& Bushika & 2020 & 15 \\
& Bumwalu & 2020 & 4 \\
& Buwali & 2020 & 57 \\
\cline { 2 - 4 } & Bukalasi & 2020 & 40 \\
Nakapiripirit & Diyok & 2020 & 2 \\
\cline { 2 - 4 } & Lokeruman & 2020 & 2 \\
\cline { 2 - 4 } & Chosan & 2019 & 2 \\
\hline Kapchorwa & Kaptanya & 2019 & 3 \\
\hline Mbale & Nambale & 2021 & 2 \\
\hline Total & & 427 \\
\hline Data source: FGDs in the study area & \\
\hline
\end{tabular}

There was an increase in temperature including warm nights, and the presence of mosquitoes due to CC, thus malaria in areas that used to be cool, e.g Kapchorwa, as reported in a related study (Obubu et al 2021). There were increased conflicts within communities and between communities and law enforcement agencies like National Forest Authority (NFA), National Environment Management Authority (NEMA), over natural resources like wetlands, fertile land, and forests; for example, Limoto wetland in the border between Pallisa and Kibuku districts. These conflicts were also reported in the fishing communities in Lake Tana, Ethiopia (Gebremedhin et al., 2018), Uganda (Hisali et al., 2011; MWE 2015), and in Southeast Asia (Francisco 2008). Measures should be undertaken to ensure that conservation and sustainable resource utilization co-exist.

Increased poverty among the local communities was reported as agriculture was not adequately productive. Lack of not only cash crops but also markets for agricultural produce was affecting family income. Hunger was reported to increase as LULC changes and CC impacts ravaged the study area in the form of floods and droughts. As a consequence of poverty and hunger, there were reported school dropouts, child labor, early child marriages, and pregnancies, and gender-based violence, where women reported husbands abandoning homes, leaving women with the burden of raising children, as was also observed in Ethiopia (Gessesew 2017), and other developing countries (Bremner et al., 2010). Participants 
reported increased disease outbreaks, including malaria and trachoma, with some claiming that even the covid-19 pandemic could be related to CC.

\subsubsection{Impacts of LULC change and climate change on water resources}

When the participants were asked about the impacts of LULC change and CC on the water resources, especially Lake Kyoga, those from Serere, Kumi, and Pallisa districts near the lake, pointed out several impacts. For example, flooding at the lake shores, especially following the heavy rains was more frequent now than 40 years ago. Indeed, the years 2007, and 2020 were pointed out as having had the most damaging floods, with the floods of the year 2020 leading to the breaking of the water level record of 1964 (Table 6). Meanwhile, the data obtained from the MWE was used to map the 2020 floods to show the extent of spread and was found to support the observation from the local communities, (Figure 6). The analysis showed that the spatial extent of the lake expanded by $12.2 \%$.

The 2020 floods did not affect only L. Kyoga but also other major lakes in the country. A summary of the water levels of three major lakes in Uganda is given in Table 6.

Table 6

Record-breaking water level trends for major Ugandan lakes

\begin{tabular}{|c|c|c|c|c|}
\hline \multicolumn{5}{|c|}{ Water levels (m) } \\
\hline SN & Lakes & 1964 (an old record) & 2020 (new record) & Difference \\
\hline 1 & Kyoga & 13.25 & 14.41 & 1.16 \\
\hline 2 & Victoria & 13.41 & 13.48 & 0.07 \\
\hline 3 & Albert & 14.2 & 14.68 & 0.48 \\
\hline
\end{tabular}

Lake Kyoga was the most affected by these floods, as pointed out by the participants during the FGDs and KIls, which agreed with the data from the MWE (see Table 6 and Figure 7). The water level data gaps in the 1980s to 1990 s were caused by the insurgency, which interrupted data collection. Lakes Kyoga and Victoria reached new record levels in May 2020; meanwhile, L. Albert, located downstream of the two lakes, broke the record in October 2020.

The participants and the literature reviewed on the floods in L. Kyoga agreed on the damages caused by floods on people, infrastructure, animals, and crops, which resulted in hunger, poverty, and malnutrition, especially among children. They also affected fishing through floating suds, which blocked landing sites, interfered with boat landing and leaving, and water supply to the riparian communities as observed in Mugarama and lyingo landing sites, in Serere and Buyende districts respectively. This was also observed 
in other parts of the world (Keskinen et al., 2010; Kundzewicz et al., 2014). The fishing community also reported a reduction in fish catches, destruction of fish breeding sites, increase in siltation of the lake and wetlands, poor water quality, increased risks of attack from reptiles like crocodiles, snakes, and monitor lizards. Further, the area witnessed a higher abundance of mosquitoes, with increased incidences of malaria according to participants.

Application of agrochemicals in the catchment and soil erosion contributes to pollution of Lake Kyoga and the observed brown water in the rivers laden with sediments, as has been pointed out by other authors (Ogutu-Ohwayo et al., 2013; Andama et al., 2017). On the other side, floods helped drown and flush out the invasive weed, Salvinia molesta from L. Kyoga, although it also helped spread it into the catchment and could indeed lead to its reinvasion later, as reported in other studies (Oliver 1993; McFarland et al., 2004; Lal 2016). The FGDs confirmed that the local communities had rich knowledge and experience of environmental issues. This presents an opportunity for engaging the community members in environmental protection and conservation practices.

Pollution of L. Kyoga has exposed it to invasion by invasive water weeds like S. molesta. When the participants however were asked why L. Kyoga was invaded by invasive water weeds, especially $S$. molesta and water hyacinth; there were varied responses. Some participants thought minister Nankabirwa brought it, others said it was from L. Victoria, while some pointed out nutrient enrichment from the catchments, warm water, the many bays where the weeds are protected, slow water flow as contributing factors, and others said it was the act of 'god.' These responses were similar to the scientific findings (Ogutu-Owahyo et al., 2013; Wanda et al., 2015; Andama et al., 2017), although the local community knowledge showed more details, which are often missed when only scientific approaches are used. This research shows the importance of integrating scientific knowledge with social or communitybased perceptions, observations, and experience to identify causative factors for environmental degradation, hence developing more reliable and lasting sustainable solutions to the environmental and $\mathrm{CC}$ issues. The participants listed consequences of invasion by the weeds, including fish kills, reduced oxygen, and difficulty in navigation.

On the massive fish kills especially of Nile perch in Lake Kyoga in 2020, the participants outlined the possible causes as pesticides in household sprays and from the gardens in the catchments drained to the lake through floods, increased heat in the water, Nile perch diseases, and poison fishing was. Meanwhile, the joint report on the massive death of Nile perch issued by the Ministry of Agriculture, Animal Industry and Fisheries (MAAIF 2020) pointed out reduced dissolved oxygen levels. The reduction in dissolved oxygen could have been caused by deposits of organic matter drained by the floods and drowned $S$. molesta. The decomposition of these organic matter by aerobic bacteria could have resulted in the reduction of dissolved oxygen, hence the death of Nile perch, which is sensitive to low oxygen levels of less than $2.5 \mathrm{mg} / \mathrm{l}$ (hypoxia condition) (Goudswaard et al., 2011). Both the community and scientific views are in consonance, hence are important for management purposes. 


\subsubsection{Linkage of LULC change and CC from catchments to the lake}

One of the main objectives of this social part of the research was to find out whether the local communities were aware that LULC change activities in the catchment and CC had an impact on the water quality of rivers and L. Kyoga. When the question of connectedness was posed to the FGDs and KIIs, the response was a resounding no. The participants in all groups, from the upstream, mid, and downstream, even those at the landing sites, were unaware that catchment activities were impacting the water quality of Lake Kyoga. As a result, the researcher educated the participants on the relationship between LULC changes and CC in the catchment and their adverse impact on water ecosystems. This finding exposed a perception gap in the connectivity between land and water and calls for awareness of the linkage. There was, therefore, a strong recommendation by participants on sensitization of the local communities on this matter. The issue of LULC change activities in the catchments being responsible for the water quality of the receiving water bodies has been well researched and proven elsewhere (Donohue et al., 2006; Miranda et al., 2014), but are still a challenge in Uganda. These findings illustrate the importance of integrating scientific and local knowledge to manage natural resources better. The participants requested feedback on the research findings and increased the extent of sensitization.

\subsection{Responses to LULC change and climate change impacts}

This component of the DPSIR has responses from different sections of society, including local community coping mechanisms, central and local government responses.

\subsubsection{Local community coping mechanisms}

The participants gave a list of coping mechanisms to alleviate the impacts of LULC changes and CC, shaped by prolonged exposure to these impacts. These included moving to urban centers for business purposes since the land was too fragmented for agriculture. The use of agrochemicals to improve crop and animal production, tree planting to combat CC impacts, and meeting timber and firewood demands. For those communities near water bodies, migration and land acquisition from other safer areas and even in other districts were reported. For example, people from Pallisa reported moving to nearby districts like Serere. Use of crop rotation, although they still said this was ineffective since the soils had lost fertility. Planting of quick maturing and drought-resistant crops, like the peanut variety "Serenut" was reported in Kumi and Serere, and eating once a day during a food shortage, or the use of relief foods from the government for seriously affected communities. Some people often resort to offering cheap labor to those who can provide for their needs, as was also reported by Hisali et al., (2011). Others have reduced the number of domestic animals, especially cattle, goats, and sheep, due to shortage of grazing land, especially in the districts of Serere, Kumi, Ngora, and Soroti, which used to be semi-nomadic. Others have resorted to dairy farming, reared on the zero-grazing regime, reducing the number of animals. People hire gardens for a season(s) from those with more land, while others practice aquaculture in wetlands as an alternative livelihood. Small scale irrigation, using valley tanks and solar-powered pumps like in Limoto 
wetland in Pallisa has been used to mitigate LULC change and CC impacts. The respondents, however, wanted more significant irrigation projects from the MWE. In Kameke Pallisa, the Kameke wetland was protected by the local community, as they appreciated its value, a rare positive occurrence that needs to be promoted in other areas. Other farmers have formed cooperative societies like Pallisa to improve their income through agriculture. Unfortunately, some families give up their girl children to early marriages to earn money to live on, and participants also reported child labor. Given the increasing community and individual conflicts due to the shortage of land resources, the communities adopted several conflict resolutions approaches, including mediation. It was important to note that the elite need consultancies to develop these measures, but the local communities apply them regularly. They may not have the resources to implement all their coping mechanisms, but they have a wealth of experience that needs to be tapped for better LULC change and CC management.

The local communities expressed challenges about coping mechanisms; these included the unreliability of fast-maturing, drought-resistant crops and exotic tree varieties. Participants in Kumi, Serere, and Pallisa districts, noted that the improved crops (cassava and groundnuts) showed a reduction in productivity within two years and were vulnerable to pests and diseases. Meanwhile, exotic trees were destructive to the environment. Relief food for the hungry was not always forthcoming unless major disasters, like landslides in Bududa, attracted the national public concerns and humanitarian response from the central government. Some interventions, like irrigation at a small scale, needs capital, which was not readily available for the local farmers unless external assistance was offered.

Participants agreed that family planning was a better approach to managing the ever-growing population, but the negative perceptions prevented its implementation. Negative perceptions included adverse effects, including over bleeding, failure to conceive following their use, or giving birth to deformed children, and the demand by men for more children. Relatedly, many women feared that when they adopted family planning measures, their husbands would engage in extra-marital affairs with other women to produce children. There is a need for the Ministry of Health $(\mathrm{MoH})$ to carry out more sensitization to both women and men to assure the public about the benefits and how to mitigate any side effects of different family planning measures. This could help reduce the ever-growing population in the study area, expected to reach over 12 million in 2030 (UBoS 2020). This study has shown that family planning approaches are not being applied.

\subsubsection{Institutional responses}

There were several institutional response activities in the study area led by the MWE, through its regional offices under KWMZ. This office works with other agencies like NEMA, NFA; ministries like Ministry of Trade and Cooperatives (MTC); Local governments (LGs); research institutions like National Semi-Arid Resources Research Institute (NaSARRI) in Serere, universities, religious and cultural institutions, local councils (LCs) and the media. These institutions work together with various projects which are focused on mitigation of LULC changes and CC impacts. The sources of funds are mainly from the Government of Uganda (GoU), grants, and donor funds acquired through projects (Table 7), like the Enhancing 
Resilience of Communities to Climate Change through Catchment Based Integrated Management of Water and Related Resources in Uganda (EURECCCA).

Table 7

Response to LULC changes and CC impact projects in L. Kyoga basin

\begin{tabular}{|c|c|c|c|c|}
\hline SN & Project & $\begin{array}{l}\text { Source of } \\
\text { funding }\end{array}$ & $\begin{array}{l}\text { Area of } \\
\text { interest }\end{array}$ & Catchment (s) \\
\hline 1 & KWMZ & GoU-MWE & Drawing CMPs & $\begin{array}{l}\text { Awoja and } \\
\text { Mpologoma }\end{array}$ \\
\hline 2 & EURECCCA & $\begin{array}{l}\text { Green } \\
\text { Adaptation }\end{array}$ & $\mathrm{CC}$ resilience & Awoja \\
\hline 3 & Green future farming, AID environment & $\begin{array}{l}\text { Dutch } \\
\text { government }\end{array}$ & Agriculture & Awoja \\
\hline 4 & $\begin{array}{l}\text { Integrated Water Management } \\
\text { Development Project (IWMDP) }\end{array}$ & World Bank & Water supply & Awoja \\
\hline 5 & $\begin{array}{l}\text { International Union for conservation of } \\
\text { nature (IUNC) }\end{array}$ & IUCN & Drawing CMPs & $\begin{array}{l}\text { Awoja, } \\
\text { Mpologoma, and } \\
\text { Lhakhakha }\end{array}$ \\
\hline 6 & $\begin{array}{l}\text { Support to resilient initiatives in } \\
\text { vulnerable entities (STRIVE) project }\end{array}$ & Water aid & $\begin{array}{l}\text { CC resilience, } \\
\text { WASH } \\
\text { facilities }\end{array}$ & Mpologoma \\
\hline & CMPs & \multicolumn{3}{|c|}{$\begin{array}{l}\text { Catchment Management } \\
\text { Plans }\end{array}$} \\
\hline & GoU & \multicolumn{3}{|c|}{ Government of Uganda } \\
\hline
\end{tabular}

The responses focused on the restoration of degraded wetlands, forests, and land, although they had different focus components. Their scope was small, and most of them were pilot projects covering small areas. The MWE, through KWMZ, used funds from the EURECCCA project, acquired from Adaptation Fund through Sahara and Sahel Observatory (OSS), to demarcate and restore some wetlands in Awoja catchment, including Oongino in Kumi, Kamurojo in Serere, Adoka in Ngora, Asubakiakiteng in Katakwi, and Limoto in Pallisa-Kibuku. Sections of riverbanks have also been restored, such as rivers Manafwa, Kere, Tabagon-chepiakamit, and Siti-Greek, to reduce siltation on the downstream lakes, protect river banks, and reduce floods. Water soil conservation activities by the construction of soil and water retention pits, and flood control structures, were implemented to increase groundwater recharge and soil moisture, increasing crop production. This was aimed at controlling rampant soil erosion, especially on the slopes of Mt. Elgon. Demonstration wetlands were also established in Amurojo, Serere, and Adoka to teach local communities how to co-exist and use wetland resources sustainably. Further, the wetlands department of the MWE has developed an inventory of wetlands with risks in the country and is 
implementing a global CC project which, encourages vegetation growth and tree planting in river banks, wetlands, and bare land.

Communities that depended on these wetlands and riverbanks as their source of livelihoods, hence degraded them, were given alternative livelihoods. These included the formation of a water and environment cooperatives society revolving funds planned by the EURECCCA project, facilitated by MTC and LGs. Construction of fish ponds in Limoto wetland and introduction of piggery as a source of income was done. Others included mushroom farming, in Kumi, Ngora, Soroti, and Serere districts. Restoration and conservation of forests have been done by the planting of indigenous trees and bamboos on the steep slopes and critically degraded catchments by the EURECCCA project. Individuals, groups, and schools participated, with over 725,000 trees planted and about 660 ha of bare land restored. Seedlings and extension services were provided locally by NaSARRI. Relatedly, the production of energy-saving stoves, called 'Lorena' fire-shielded (target was 4,200 ) to local community women groups was also done to conserve forests and trees, improve health by reducing smoke and save time used while looking for firewood. Most of the interventions have not emphasized measures that encourage terracing in the steep slopes, yet they are essential.

Response contributions of other projects like IUCN in developing catchment management plans (CMPs) for implementation by other projects were necessary. Projects like IWMDP, and STRIVE focused on increasing community resilience to $\mathrm{CC}$ by supplying drinking water to households and livestock to mitigate water scarcity caused by $\mathrm{CC}$ impacts. These interventions were vital in mitigating the impacts of LULC change and CC and achieving sustainable development goals (SDGs). Goal 6, focused on clean water and sanitation for all in 2030, and goal 15, aimed at protecting, restoring, and promoting sustainable use of terrestrial ecosystems, especially forests and land, including combating desertification and reversing biodiversity loss (UNCCP 2018), are prime targets. However, during the FGDs and KIls, communities appreciated the Lorena energy-saving stoves, but also recognized tree planting efforts, although they said the survival rate was low.

\subsubsection{Policy and regulation response}

Uganda has good Policies, Acts of Parliament, and Regulations regarding environment protection and CC; the challenge is their weak implementation. If they were implemented effectively, the observed adverse impacts would be reduced. For example, the Uganda National Policy on Climate Change calls on all stakeholders to manage CC impacts and causes through the promotion of a green economy for sustainable development (UNCCP 2018), which is not being realized. Uganda is also a signatory to many CC conventions and protocols, like the Kyoto protocol of 1997, on the reduction of greenhouse gas emissions and the Rio Summit of 1992. The National Environment Act, Cap 153, through the National Environment (wetlands, riverbanks, and lakeshores management) regulations, No. 3 of 2000 sets buffer zones for rivers, and wetlands at 100 meters, lakes at 200 meters (NER 2000), but these are not being followed. The National Forestry and Tree Planting Act of 2003 encourages all people to plant trees and also prohibits the destruction of forests, except under authorization by the responsible authorities. National Agricultural Policy recognizes agriculture as a driver of national economic growth, the biggest 
source of food and employment. It also recognizes the vital role environment and natural resources play in achieving agricultural objectives. It, therefore, recommends sensitization of the population on the use and conservation of the critical resources, which are soils and water, through extension services (NAP 2013). The National Urban Policy (NUP), through the Town and Country Act of 2000, the National Urban Policy (NUP), and the Physical Planning Act of 2010, are responsible for urban land use and planning (NUP 2017). Among other objectives, the policy seeks to promote urban environmental protection and conservation, develop adaptation and mitigation measures against CC. Through the National Environment (standards for discharge for effluents into water or land) Regulations (NWR 2020), the Water Act prohibits the discharge of industrial and domestic point source effluents into the environment or water that does not meet the set standards. But most of the effluent quality of the domestic wastes in the study area did not meet these standards, over the years, without any punitive action taken against the companies responsible.

The most significant challenge is the implementation of these legislations since the enforcement arms are either missing or weak. Where the penalties are provided for defaulters, they are not adequately punitive or are not enforced. Meanwhile, some of the provisions of legislation need to be revised to include critical missing areas. For example, the national forestry and tree planting Act should include a section on the follow-up of the people or organizations that plant trees to make sure trees are cared for and survive. Local communities also recommended punishment for individuals and organizations that fail to care for trees and reward the responsible tree planters. There should be regulations on the application of agrochemicals to operationalize National Agricultural policy since there are fake products in the market.

\subsubsection{Challenges of mitigation of land use, land cover, and climate change impacts}

The institutional response interventions were short-lived and only covered small areas as pilot projects. Therefore, there is a need to expand them, which requires more funds given the expansive nature of LULC change and CC impacts. When the interventional projects reach their lifetime, it is often expected that GoU, through MWE, LGs, and communities, would continue implementing the objectives to ensure the sustainability of their outputs, but this is seldom the case due to a shortage of technical, financial, and infrastructural resources. As a result, in most cases, the end of pilot projects' lifespan implies the end of implementing their respective ideas, hence limiting their impact. Meanwhile, the Covid-19 pandemic was one of the challenges that affected the effective implementation and supervision of the project activities. Shortage of land, lack of alternative livelihoods, and the ever-growing population have made the population encroach on protected areas. Hence, the restoration of wetlands and forests is not entirely accepted by local communities, even when involved in these interventions. Local communities often have resistance and incidences of violent confrontation against law enforcement officers and intervention staff, exposing them to danger during demarcation exercises, as was reported in Adoka and Oongino villages during wetland demarcation and restoration. 
Since the constitution gives land rights to individuals, restoration interventions are often viewed by the public as schemes to 'grab' land and are resolutely resisted. Climate change itself was identified as a challenge to the interventions because prolonged dry weather affects the survival of planted trees. Also, superstitious beliefs and attitudes of some of the members of the communities, which are generally "resigned to fate as it were," are unhelpful for conservation efforts since they do not accept that interventions such as tree planting and restoration of wetlands can mitigate against effects of LULC change and $\mathrm{CC}$ impacts. Therefore, to ensure the adoption of recommended interventions by local communities, such attitudes need to be changed through sensitization, which takes time. In some cases, seedlings were supplied to the communities during the dry season or towards the end of rainy seasons, which would substantially reduce the chance of survival since there were no options for irrigation. New fast-growing crops promoted as coping measures against CC were prone to pests and diseases, thus requiring the use of agrochemicals to ensure good production. Therefore, the communities recommended indigenous trees, such as fruit trees, and reintroducing indigenous crop varieties, like cassava, including cash crops, like cotton.

There was a strong sentiment by institutions and the local communities on political interference of environmental management activities. To gain popularity, often politicians conveyed conflicting ideas and signals to the public, leading to incitement, resistance to restoration, and conservation efforts by the government and other stakeholders. These political leaders often hold more power over their constituents and are respected by the communities, who are therefore negatively influenced, leading to low adoption of appropriate LULC and CC mitigation measures. This was reported in Ngora, Pallisa, Kibuku, and Kumi districts.

\subsection{Conclusion}

The LULC changes and CC have been proven in the Lake Kyoga basin by both scientific and local community perceptions. Whereas population was the main underlying driver of LULC change and CC, agriculture was the major pressure on the natural resources. The study of LULC change and CC together, especially at the local level should be the new paradigm shift in identifying their drivers and impacts on water and the environment, for management purposes. It is also important to integrate pure scientific approaches and social sciences when coming up with mitigation measures against impacts of LULC changes and CC. This is critical since scientific study alone without integration of the social knowledge is inadequate in the development of local sustainable management tools. LULC change alone would have limited impacts, especially in water without CC. CC exacerbates impacts of the degradation of land, by helping to deliver nutrients and sediments into the receiving water bodies through rivers and streams. There any efforts to mitigate LULc change impacts should incorporate CC. There were many impacts of LULC change and CC in the study area that were articulated by the local communities. These include displacements, deaths, hunger, poverty, loss of infrastructure, loss of biodiversity, and conflicts. Although there are policies and legislation to mitigate drivers and impacts of LULC change and CC, they are not being applied fully. The use of cultural values to manage and protect natural resources as brought forth by this study is one of the management measures that should be pursued. The local communities are 
rich in knowledge about environmental and CC threats around them, they are only challenged by a lack of resources and leadership for the development of sustainable interventions and mitigation measures.

FGDs and KIIs are key social science approaches that should become key in the identification and development of sustainable management approaches as they allow interaction with the affected local communities, thus integrating their valuable perceptions on any interventions. This study has underscored the need for an integrated approach to the management of natural resources, as the threats do not work in isolation, but rather synergize to cause major impacts. The Ministry of Health needs to be involved to sensitize the public on the advantages of family planning since the population is the major cause of LULC change.

\subsection{Recommendations For Management Options}

Most of the response projects have proved successful; however, they had a short lifespan and covered small areas as pilots. For example, the soil water conservation practice by the construction of soil and water retention reservoirs and flood control structures. This should be expanded to cover hilly and steep slope areas of Bukwo, Bududa, Kween, Kapchorwa, and Sironko districts. Demarcation and restoration of wetlands and forests areas should be done using available regulations, and local communities should be encouraged to plant trees in woodlots. Terracing on the steep slopes of Mt. Elgon should be encouraged and done to reduce soil erosion. Therefore, MWE needs to design more significant conservation projects in collaboration with other line ministries like MAAIF, Ministry of Finance Planning and Economic Development (MFPED), and lobby funds locally and internationally for their implementation. This will mitigate against pollution of rivers, wetlands, and Lake Kyoga.

Before any restoration of wetlands, forests, and degraded lands is undertaken, it is essential to seek community buy-in, support, and participation. The leaders (political, religious, and cultural) should be consulted and coopted. Sound and viable alternative sources of income need to be put in place and agreed upon by the affected communities. If necessary, bylaws may be drafted to punish members, including leaders who deviate from abiding by agreed steps for respective projects.

Integration of cultural values into the management of natural resources should be given priority. Most communities respect cultural values; for example, in Pallisa, some hills were protected as cultural celebrations and sacrifice areas. In Nakapiripirit, cutting big trees was prohibited as they were revered as having "gold" and attracting "rains,"; while in Bududa, wetlands were treated as cultural grounds. When these cultural beliefs are integrated into natural resources management, it will be a better local solution, thus cultural leaders are very important in mitigation measures.

Since food production is the most considerable pressure of LULC change and CC, expansion of irrigation should be prioritized by the MWE. Climate change in the form of droughts and heavy rains affects the study area; storage of rainwater during excess rains through the construction of water reservoirs, which would be used for irrigation, domestic and animal watering during droughts should be done.

Communities also recommended the growing of upland rice to reduce pressure on wetlands. Further, the 
local communities recommended that irrigation programs be ensured for both individuals and groups, not the current MWE policy of prioritizing groups only.

There should be reviews of policies, laws, and regulations to match the current LULC changes and CC impacts in the study area and throughout the country, since most of these policies were made long ago. The enforcement sections should be included in the regulations and budgeted for if the legislation results are to be realized on the ground. For example, the National Forestry and Tree planting Act should include in its regulation sections that force people to plant trees, like the principle of "cut one tree, plant two". Planting of trees in land boundaries, at roadsides in towns, in health centers, hospitals, schools, and in peoples' compounds should be put into regulations. Recognition of the compliant individuals and institutions and punishment for defaulters should be part of the regulation. The integrated approach is, therefore, key to achieving holistic and sustainable management of LULC changes and CC. The Ministry of health should be instrumental in promoting family planning in the communities. There should be some incentives for families that adopt family planning.

To get the farmers out of poverty, which was identified as one of the pressures for LULC changes and CC, markets for agricultural products and the establishment of value addition should be a priority. This could be achieved by reintroducing cooperative societies, a move the government seems to pursue as recommended by the National Agricultural Policy. There should be regulation by MAAIF on the use of agrochemicals that are not being regulated. Otherwise, with the overall poverty levels in the country, natural resources will continue to degrade.

The communities also requested for recruitment of more agricultural extension workers by MAAIF and their deployment at the sub-county level. Key informants had fond memories of over 40 years ago when extension workers worked closely with farmers and were helpful. They said the current extension workers are not in touch with the farmers and are thin on the ground.

Other recommendations from the study included zoning of the country agriculturally according to the suitable crops/animals for the particular climate and soils. Artisanal mineral mining activities, especially in the Karamoja and Tororo areas, are not conventional; communities complained of pollution from the crude mining methods. Mining should be formalized, and conventional approaches should be applied to reduce pollution of the environment and water resources.

The MWE, through Uganda National Meteorological Authority (UNMA), should improve the accuracy of weather forecasts and broaden the delivery of the forecasts to help farmers plan appropriately. The use of print media, television, radio, and social applications to pass out information to the communities should be encouraged. This study is unique to this area of study, and its findings are relevant since they are from the local communities; it should therefore be replicated in other parts of the country and region. Policy-makers and analysts, water, environment

\section{Declarations}


Ethics approval and consent to participate: Not applicable

Consent for publication: Not applicable

Availability of data and materials: Part of the data used in this research is available with the corresponding author on request. The Lake Kyoga water level data can be obtained from the Ministry of Water and Environment (MWE) on request. The Ministry can be contacted on the website https://www.unma.go.ug/. P.O. Box 20026, Kampala Uganda.

Competing interests: The authors declare that they have no competing interest in the production and publication of this manuscript.

Funding: The funding for the production of this research work was through the $\mathrm{Ph}$. D scholarship offered to the corresponding author at Africa Centre of Excellence for Water Management (ACEWM), Addis Ababa University, Addis Ababa, Ethiopia. The Grand number (ACEWN/GSR/9873/11), is sponsored by the World Bank Group.

Authors' contributions: The corresponding author (John Peter Obubu), a Ph. D student at Addis Ababa University under the Africa Centre of Excellence for Water Management, came up with the topic, designed and planned the research work, with the guidance of supervisors. He collected and analyzed data, drafted the original draft manuscript, and incorporated all comments from the supervisors. RO, reviewed, helped in the development of the results summary table, and edited the contents of this manuscript. TA, edited the manuscript, helped in data analysis, provided useful comments that guided the writing of the manuscript. TF reviewed and edited the draft manuscript, and provided important comments that enriched the manuscript. SM played an important advisory role and also revised and edited the manuscript.

Acknowledgments: The authors would like to acknowledge the contribution of the Africa Center of Excellence for Water Management (ACEWM) for the guidance before and during the study period. Special appreciation also goes to the Ministry of Water and Environment (MWE) Uganda, for providing working space and data, the field team, district community development officers, and all participants during the FGDs and KIls. National Water and Sewerage Corporation (NWSC) is especially appreciated for providing water quality and water treatment data.

Authors' information (optional): Not applicable

\section{References}

1. Agyemang I, McDonald A, Carver S (2007) Application of the DPSIR framework to environmental degradation assessment in northern Ghana. Natural Resources Forum, vol 31. Blackwell Publishing Ltd, Oxford, UK, pp 212-225. 3 
2. Agyemang I (2012) Assessing the driving forces of environmental degradation in Northern Ghana: Community truthing approach. African Journal of History and Culture 4(4):59-68

3. Akhtar A, Rashid SM, Bhat MS, Sheikh AH (2011) Impact of land use/land cover dynamics on Himalayan wetland ecosystem. Journal of Experimental Sciences 2(3):60-64

4. Alemayehu F, Taha N, Nyssen J, Girma A, Zenebe A, Behailu M, Poesen J (2009) The impacts of watershed management on land use and land cover dynamics in Eastern Tigray (Ethiopia). Resour Conserv Recycl 53(4):192-198

5. Andama, M., Ongom, R., Lukubye, B., 2017. Proliferation of Salvinia molestaat Lake Kyoga Landing Sites as a Result of Anthropogenic Influences. J. Geosci. Environ.Prot. 05, 160-173. https://doi.org/10.4236/gep.2017.511012

6. Amjath-Babu TS, Krupnik TJ, Aravindakshan S, Arshad M, Kaechele H (2016) Climate change and indicators of probable shifts in the consumption portfolios of dryland farmers in Sub-Saharan Africa: Implications for policy. Ecol Ind 67:830-838

7. Anaba LA, Banadda N, Kiggundu N, Wanyama J, Engel B, Moriasi D (2016) Application of SWAT to assess the effects of land-use change in the Murchison Bay catchment in Uganda

8. Ashfaq MY, Al-Ghouti MA, Qiblawey H, Zouari N, Rodrigues DF, Hu Y (2019) Use of DPSIR framework to analyze water resources in Qatar and overview of reverse osmosis as an environment-friendly technology. Environ Prog Sustain Energy 38(4):13081

9. Assembly G (2015) Sustainable development goals. SDGs Transform Our World, 2030

10. Belay KT, Van Rompaey A, Poesen J, Van Bruyssel S, Deckers J, Amare K (2015) Spatial analysis of land cover changes in Eastern Tigray (Ethiopia) from 1965 to 2007: are there signs of a forest transition? Land Degradation \& Development 26(7):680-689

11. Bisaro A, Kirk M, Zdruli P, Zimmermann W (2014) Global drivers setting desertification research priorities: insights from a stakeholder consultation forum. Land Degradation \& Development 25(1):5-16

12. Bone RA, Parks KE, Hudson MD, Tsirinzeni M, Willcock S (2017) Deforestation since independence: A quantitative assessment of four decades of land-cover change in Malawi. Southern Forests: a Journal of Forest Science 79(4):269-275

13. Bremner J, López-Carr D, Suter L, Davis J (2010) Population, poverty, environment, and climate dynamics in the developing world. Interdisciplinary Environmental Review 11(2-3):112-126

14. Bu H, Meng W, Zhang Y, Wan J (2014) Relationships between land use patterns and water quality in the Taizi River basin, China. Ecol Ind 41:187-197

15. Camberlin P (2009) Nile Basin Climates. The Nile: Origin, Environments, Limnology and Human Use. Springer, Berlin, Germany, pp 307-333

16. De Sherbinin A, VanWey LK, McSweeney K, Aggarwal R, Barbieri A, Henry S, Hunter LM, Twine R (2008) Rural household demographics, livelihoods, and the environment. Glob Environ Change 18(1):38-53 
17. Donohue I, McGarrigle ML, Mills P (2006) Linking catchment characteristics and water chemistry with the ecological status of Irish rivers. Water Res 40(1):91-98

18. Dregne HE (2002) Land degradation in the drylands. Arid land research and management 16(2):99132

19. Dzoga M, Simatele DM, Munga C, Yonge S (2020) Application of the DPSIR framework to coastal and marine fisheries management in Kenya. Ocean Science Journal 55:193-201

20. Farauta BK, Egbule CL, Agwu AE, Idrisa YL, Onyekuru NA (2012) Farmers' adaptation initiatives to the impact of climate change on agriculture in northern Nigeria. $J$ of Agricultural Extension 16(1):132144. http://dx.doi.org/10.4314/jae.v16i1.13

21. Fatumah N, Tilahun SA, Mohammed S (2020) Effect of tillage systems and tillage direction on soil hydrological properties and soil suspended particle concentration in arable land in Uganda.Heliyon, 6(12), e05616

22. Francisco HA (2008) Adaptation to climate change: needs and opportunities in Southeast Asia.ASEAN Economic Bulletin,7-19

23. Gabrielsen P, Bosch P (2003) Environmental Indicators: Typology and Use in Reporting; EEA: Copenhagen, Denmark,

24. Gebremedhin S, Getahun A, Anteneh W, Bruneel S, Goethals P (2018) A drivers-pressure-state-impactresponses framework to support the sustainability of fish and fisheries in Lake Tana. Ethiopia Sustainability 10(8):2957

25. Gessesew WS (2017) Application of DPSIR framework for assessment of land degradation: A review. Forest 3(1):4-000

26. Geist HJ, Lambin EF (2002) Proximate Causes and Underlying Driving Forces of Tropical DeforestationTropical forests are disappearing as the result of many pressures, both local and regional, acting in various combinations in different geographical locations. Bioscience 52(2):143150

27. Glaser BG, Strauss AL, Strutzel E (1968) The discovery of grounded theory; strategies for qualitative research. Nurs Res 17(4):364

28. Gondwe MF, Cho MA, Chirwa PW, Geldenhuys CJ (2019) Land use land cover change and the comparative impact of co-management and government-management on the forest cover in Malawi (1999-2018). J of Land Use Science 14(4-6):281-305

29. Goudswaard PC, Katunzi EFB, Wanink JH, Witte F (2011) Distribution of Nile perch Lates niloticus in southern Lake Victoria is determined by the depth and dissolved oxygen concentrations. Afr $\mathrm{J}$ Aquat Sci 36(2):147-153

30. Harte $\mathrm{J}$ (2007) Human population as a dynamic factor in environmental degradation. Popul Environ 28(4):223-236

31. Hisali E, Birungi P, Buyinza F (2011) Adaptation to climate change in Uganda: evidence from microdata. Glob Environ Change 21(4):1245-1261 
32. Huong HTL, Pathirana A (2013) Urbanization and climate change impacts on future urban flooding in Can Tho city, Vietnam. Hydrol Earth Syst Sci 17(1):379-394

33. IPPC (2007) Summary for Policy makers-level. Climate change: Impacts, Adaptation, and Vulnerability. Contribution of Working Group II to the Fourth Assessment Report of the Intergovernmental Panel on Climate. UK Cambridge University Press

34. Juhé-Beaulaton D (2006) 2006.Economic and social issues around sacred woods and the "conservation of biodiversity", Benin, Burkina Faso, and Togo. Proceedings of the IFB workshop, Dynamics of biodiversity and modalities of access to environments and resources, Fréjus 79 September 2005, Paris, IFB:6872

35. Kabubo-Mariara J (2007) Land conservation and tenure security in Kenya: Boserup's hypothesis revisited. Ecol Econ 64(1):25-35

36. Kelble CR, Loomis DK, Lovelace S, Nuttle WK, Ortner PB, Fletcher P, Boyer JN (2013) The EBM-DPSER conceptual model: integrating ecosystem services into the DPSIR framework.PloS one, 8(8), e70766

37. Keskinen M, Chinvanno S, Kummu M, Nuorteva P, Snidvongs A, Varis O, Västilä K (2010) Climate change and water resources in the Lower Mekong River Basin: putting adaptation into the context. J of water and climate change 1(2):103-117

38. Kirui O, Mirzabaev A (2015) Drivers of land degradation and adoption of multiple sustainable land management practices in Eastern Africa (No. 1008-2016-80052)

39. Kokou K, Sokpon N (2006) The sacred forests of the Dahomey corridor. Woods and Forests of the Tropics 288:1523

40. Kristensen P (2004) The DPSIR Framework, workshop on a comprehensive/detailed assessment of the vulnerability of water resources to environmental change in Africa using river basin approach. UNEP Headquarters, Nairobi, Kenya

41. Kundzewicz ZW, Kanae S, Seneviratne SI, Handmer J, Nicholls N, Peduzzi P, Mechler R, Laurens MB, Arnell N, Mach K, Muir-Wood R, Brakenridge GR, Kron W, Benito G, Honda Y, Takahashi K, Sherstyukov B (2014) Flood risk and climate change: global and regional perspectives. Hydrol Sci J 59(1):1-28

42. Lal A (2016) Salvinia molesta: An Assessment of the Effects and Methods of Eradication. Master's Proj. Capstones 572

43. Lambin EF, Turner BL, Geist HJ, Agbola SB, Angelsen A, Bruce JW, Coomes OT, Dirzo R, Fischer G, Folke C, George PS, Homewood K, Imbernon J, Leemans R, Li XB, Moran EF, Mortimore M, Ramakrishnan PS, Richards JF, Skanes H, Steffen W, Stone GD, Svedin U, Veldkamp TA, Vogel C, Xu J (2001) The causes of land-use and land-cover change: moving beyond the myths. Glob Environ Change 11(4):261-269

44. Lambin EF, Geist HJ (eds) (2008) Land-use and land-cover change: local processes and global impacts. Springer Science \& Business Media

45. Levy PS, Lemeshow S (2013) Sampling of populations: methods and applications. John Wiley \& Sons 
46. Makwinja R, Kaunda E, Mengistou S, Alamirew T (2021) Impact of land use/land cover dynamics on ecosystem service value-a case from Lake Malombe, Southern Malawi. Environ Monit Assess 193(8):1-23

47. Martins JH, Camanho AS, Gaspar MB (2012) A review of the application of driving forces-PressureState-Impact-Response framework to fisheries management. Ocean \& Coastal Management 69:273-281

48. Matagi SV (2002) Some issues of environmental concern in Kampala, the capital city of Uganda. Environ Monit Assess 77(2):121-138. https://doi.org/10.1023/A:1015860820467

49. Maxwell JA (2012) Qualitative research design: An interactive approach. Sage publications

50. Mbogga MS (2012) Climate profiles and climate change vulnerability assessment for the Mbale region of Uganda. UNDP Consultancy report. Kampala, Uganda

51. McFarland DG, Nelson LS, Grodowitz MJ, Smart RM, Owens CS (2004) Salvinia molesta DS Mitchell (giant Salvinia) in the United States: A review of species ecology and approaches to management. Aquatic Plant Control Program. Engineer Research and Development Center, Washington DC, US

52. McKinney ML (2002) Urbanization, Biodiversity, and Conservation. The impacts of urbanization on native species are poorly studied, but educating a highly urbanized human population about these impacts can greatly improve species conservation in all ecosystems. Bioscience 52(10):883-890

53. Ministry of Water and Environment (MWE) (2013) Integrated territorial climate plan 2014-2029 for Mbale region, Uganda (Bududa, Mbale, and Manafwa districts), Kampala Uganda.

54. Ministry of Water and Environment (MWE) (2015) Catchment management for Awoja catchment.Kampala Uganda. Downloaded fromhttps://www.mwe.go.ug/ on 26 August 2021.

55. Ministry of Water and Environment (2018a) Mpologoma Catchment Management Plan. Ministry of Water and Environment, Kampala, Uganda

56. Miranda LE, Andrews CS, Kröger R (2014) Connectedness of land use, nutrients, primary production, and fish assemblages in oxbow lakes. Aquat Sci 76(1):41-50

57. Namaalwa S, Funk A, Ajie GS, Kaggwa RC (2013) A characterization of the drivers, pressures, ecosystem functions, and services of Namatala wetland, Uganda, vol 34. Environmental Science \& Policy, pp 44-57

58. National Agricultural Policy (NAP) (2013) Ministry of Agriculture, Animal Industry and Fisheries (MAAIF). Kampala Uganda

59. National Environment (Wetlands; River Banks and Lake Shores Management) Regulations (2000) Ministry of Water and Environment (MWE). Kampala Uganda

60. Nkonya E, Gerber N, von Braun J, De Pinto A (2011) Economics of land degradation: The costs of action versus inaction, IFPRI issue brief no.68

61. Nyumba OT, Wilson K, Derrick CJ, Mukherjee N (2018) The use of focus group discussion methodology: Insights from two decades of application in conservation. Methods Ecol Evol 9(1):2032 
62. Obubu JP, Mengistou S, Fetahi T, Alamirew T, Odong R, Ekwacu S (2021) Recent Climate Change in the Lake Kyoga Basin, Uganda: An Analysis Using Short-Term and Long-Term Data with Standardized Precipitation and Anomaly Indexes. Climate 9(12):179. doi:10.3390/cli9120179

63. OECD (2003) Environmental Indicators: Development, Measurement, and Use; Reference Paper; OECD: Paris, France,

64. Ogutu-Ohwayo R, Odongkara K, Okello W, Mbabazi D, Wandera SB, Ndawula LM, Natugonza V (2013) Variations and changes in habitat, productivity, the composition of aquatic biota and fisheries of $\mathrm{L}$. Kyoga system: lessons for management. Afr J Aquat Sci 38(sup1):1-14

65. Ojara MA, Lou Y, Aribo L, Namumbya S, Uddin MJ (2020) Dry spells and probability of rainfall occurrence for Lake Kyoga Basin in Uganda, East Africa. Nat Hazards 100(2):493-514. https://. DOI

66. Oliver JD (1993) A review of the biology of giant Salvinia. Liberty University

67. Onwuegbuzie AJ, Dickinson WB, Leech NL, Zoran AG (2009) A qualitative framework for collecting and analyzing data in focus group research. International journal of qualitative methods 8(3):1-21

68. Osbahr H, Dorward P, Stern R, Cooper S (2011) Supporting agricultural innovation in Uganda to respond to climate risk: linking climate change and variability with farmer perceptions. Exp Agric 47(2):293-316

69. Patton MQ (1990) Qualitative evaluation and research methods (2nd edition.). Washington DC: SAGE Publications, inc

70. Pingali P, Schneider K, Zurek M (2014) Poverty, agriculture and the environment: The case of SubSaharan Africa. Marginality. Addressing the nexus of poverty, exclusion, and ecology. Springer, Netherlands, pp 151-168

71. Porta J, Claret RMP (2011) DPSIR analysis of land and soil degradation in response to changes in land use. Spanish Journal of Soil Science: SJSS 1(1):100-115

72. Rawat JS, Kumar M (2015) Monitoring land use/cover change using remote sensing and GIS techniques: A case study of Hawalbagh block, district Almora, Uttarakhand, India. The Egyptian Journal of Remote Sensing and Space Science 18(1):77-84

73. Reynolds JF, Smith DMS, Lambin EF, Turner BL, Mortimore M, Batterbury SP, Walker B (2007) Global desertification: building a science for dryland development. Science 316(5826):847-851

74. Sandelowski M (2008) Theoretical saturation. In: Given LM (ed) The Sage encyclopedia of qualitative methods, vol 1. Sage, Thousand Oaks, CA, pp 875-876

75. Sekovski I, Newton A, Dennison WC (2012) Megacities in the coastal zone: Using a driver-pressurestate-impact-response framework to address complex environmental problems. Estuarine, Coastal and Shelf Science, 96, 48-59

76. Sun R, Chen L, Chen W, Ji Y (2013) Effect of land-use patterns on total nitrogen concentration in the upstream regions of the Haihe River Basin, China. Environ Manage 51(1):45-58

77. Sun S, Wang Y, Liu J, Cai H, Wu P, Geng Q, Xu L (2016) Sustainability assessment of regional water resources under the DPSIR framework. J of Hydrology 532:140-148 
78. Tang Z, Engel BA, Pijanowski BC, Lim KJ (2005) Forecasting land-use change and its environmental impact at a watershed scale. J of environmental management 76(1):35-45

79. Uganda Bureau of Statistics (UBoS). Uganda Population Projections. Kampala Uganda (2020) Downloaded from https://www.ubos.org on 23 September 2021

80. Uganda National Climate Change Policy (UNCCP) (2018) Ministry of Water and Environment, Republic of Uganda. Transformation through Climate Change Mitigation and Adaptation. Kampala Uganda

81. UNICEF (2020) Uganda's multidimensional poverty profile, going beyond monetary poverty. Kampala Uganda. www.unicef.org/uganda

82. Urama KC, Ozor N (2010) Impacts of climate change on water resources in Africa: the role of adaptation. African Technology Policy Studies Network 29:1-29

83. Vu QM, Le QB, Frossard E, Vlek PL (2014) Socio-economic and biophysical determinants of land degradation in Vietnam: An integrated causal analysis at the national level. Land use policy 36:605617

84. Water (Waste Discharge) Regulations (WWDR). (1998). Statutory Instruments: Under section 107 of the Water Act, Cap 152,Kampala Uganda

85. Wan R, Cai S, Li H, Yang G, Li Z, Nie X (2014) Inferring land use and land cover impact on stream water quality using a Bayesian hierarchical modeling approach in the Xitiaoxi River Watershed, China. J of Environmental Management 133:1-11

\section{Figures}




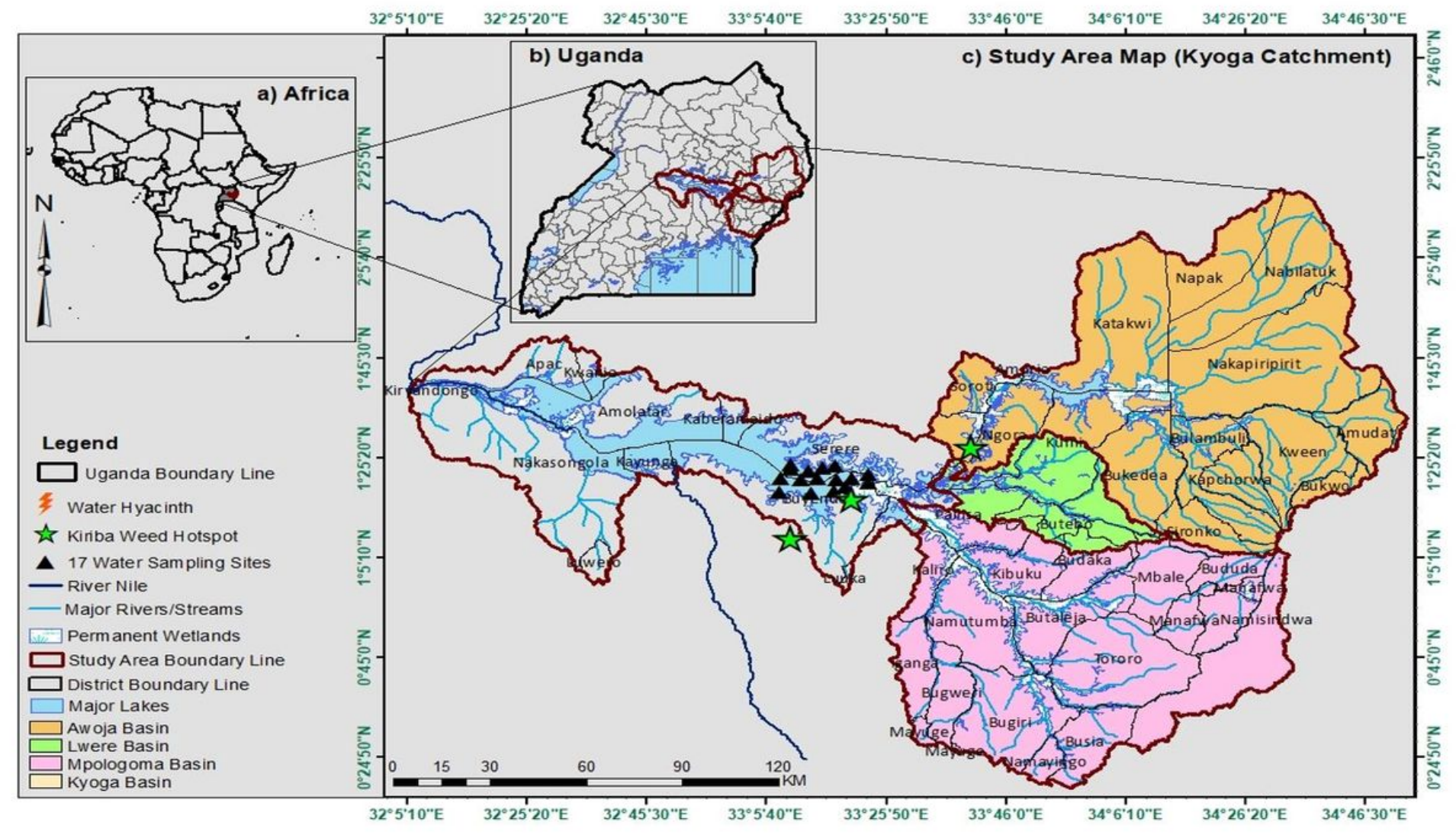

\section{Figure 1}

the location of the study area
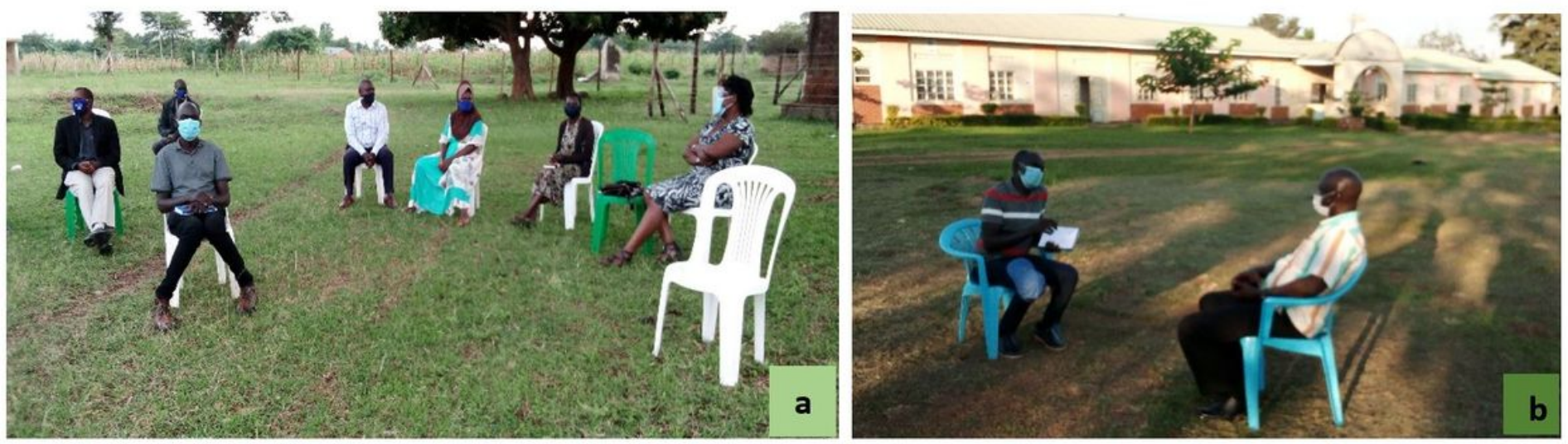

Figure 2

A section of an FGD in Busiu Mbale (a) and KII (b) in Pallisa, pictures by the researcher 


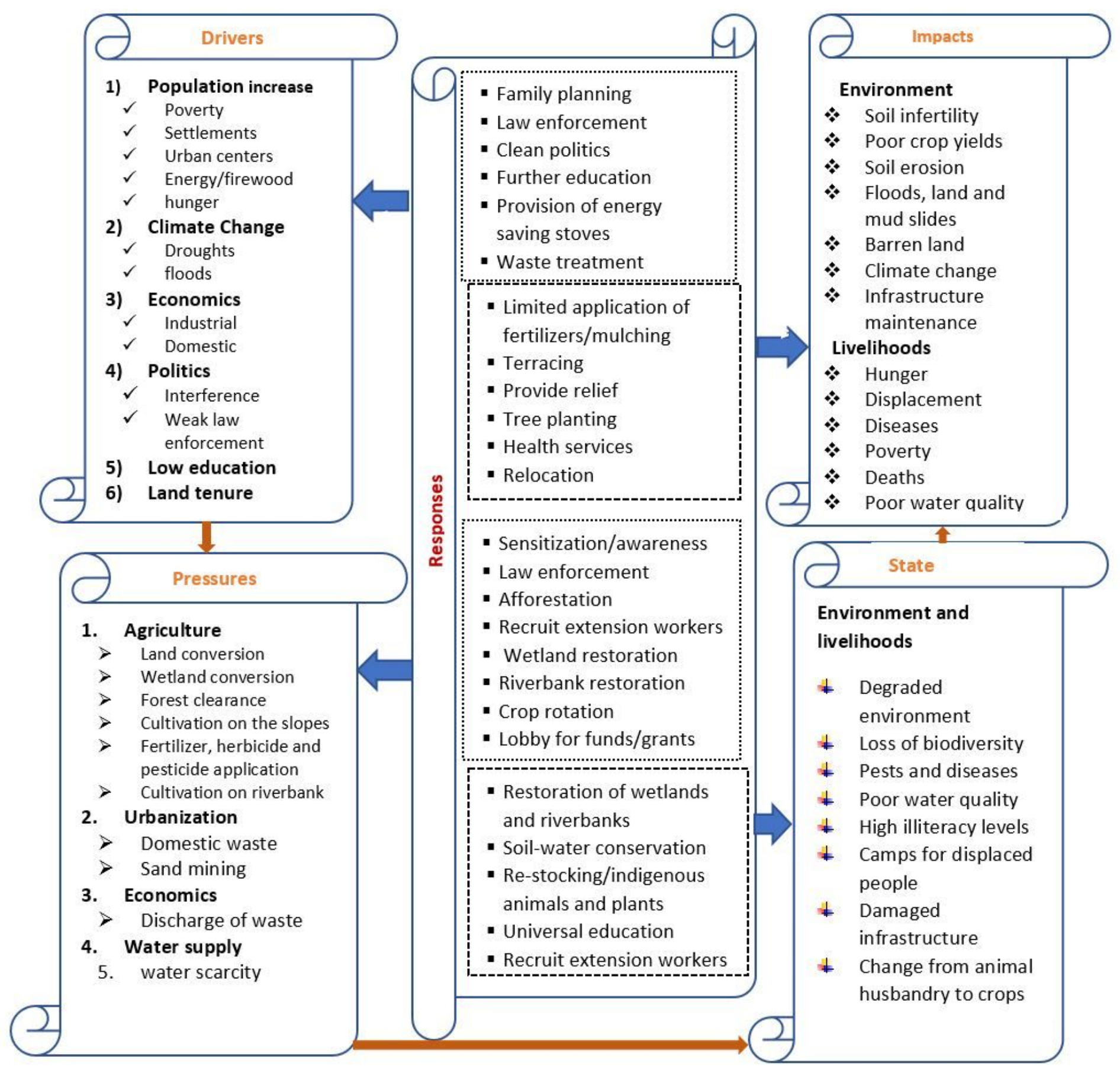

Figure 3

DPSIR framework model of the findings of LULC change and CC in the study area 


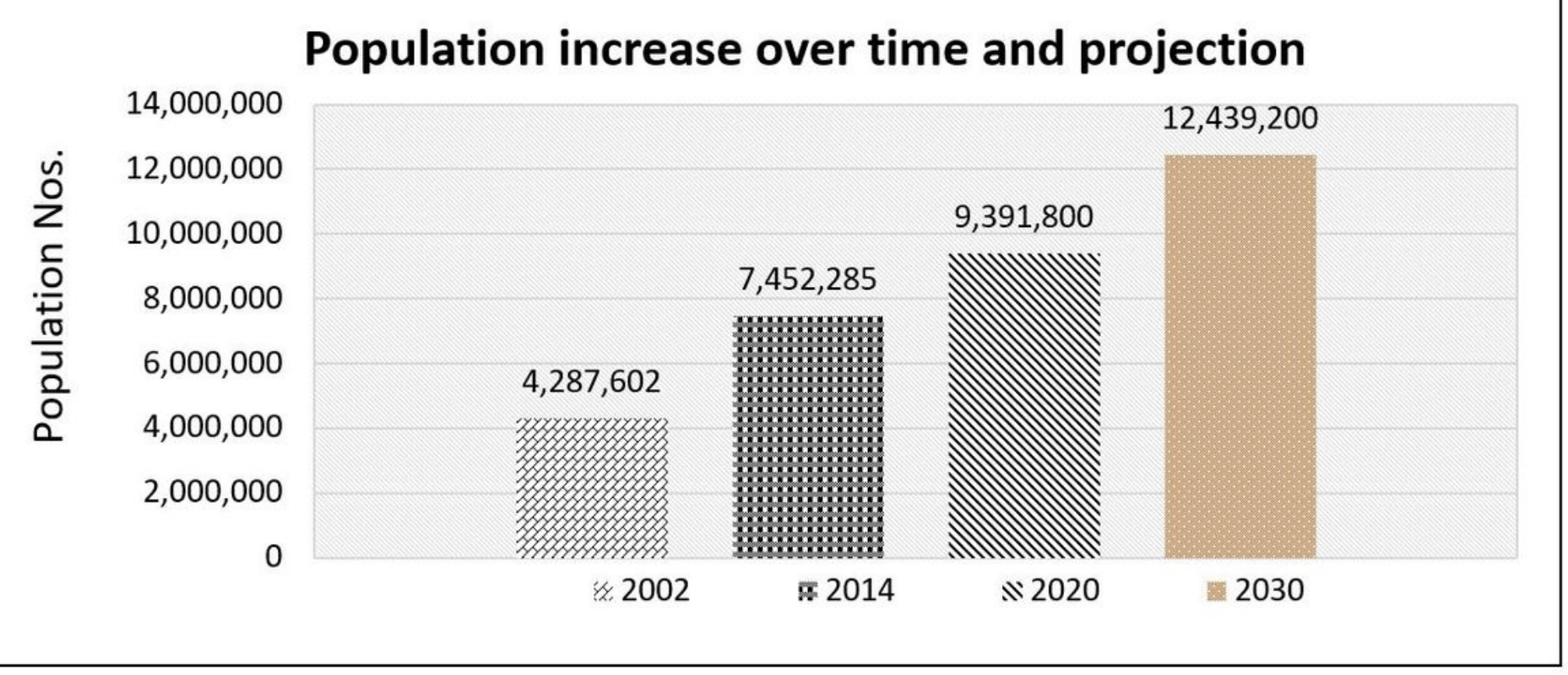

\section{Figure 4}

Population dynamics over the study period (2000-2020) and projections for 2030.
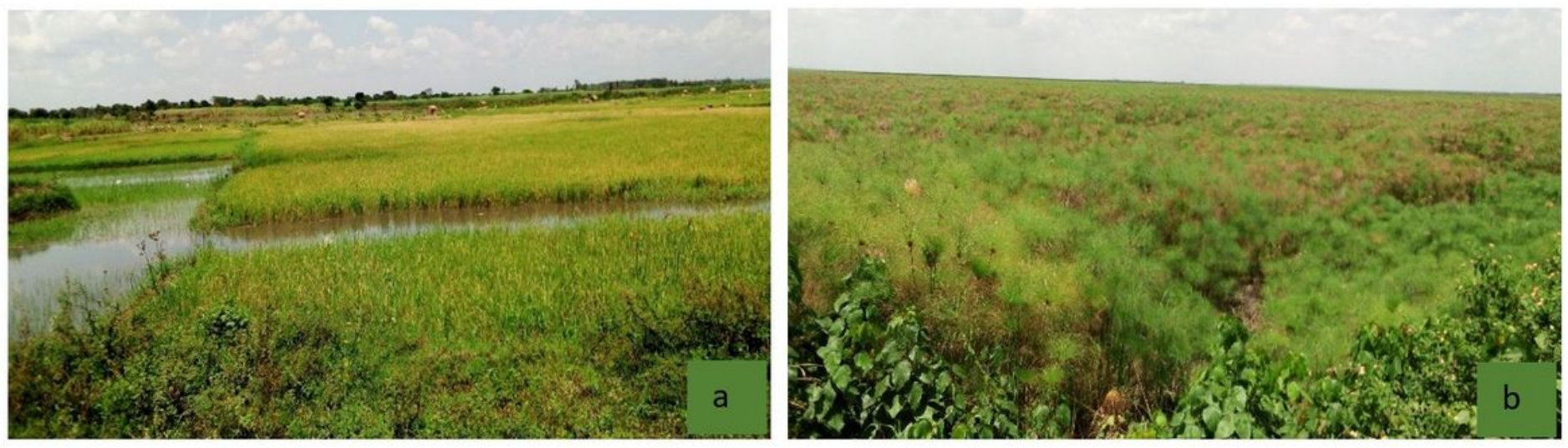

Figure 5

Parts of Mpologoma wetland, (a) converted for growing rice; and (b) intact wetland area 


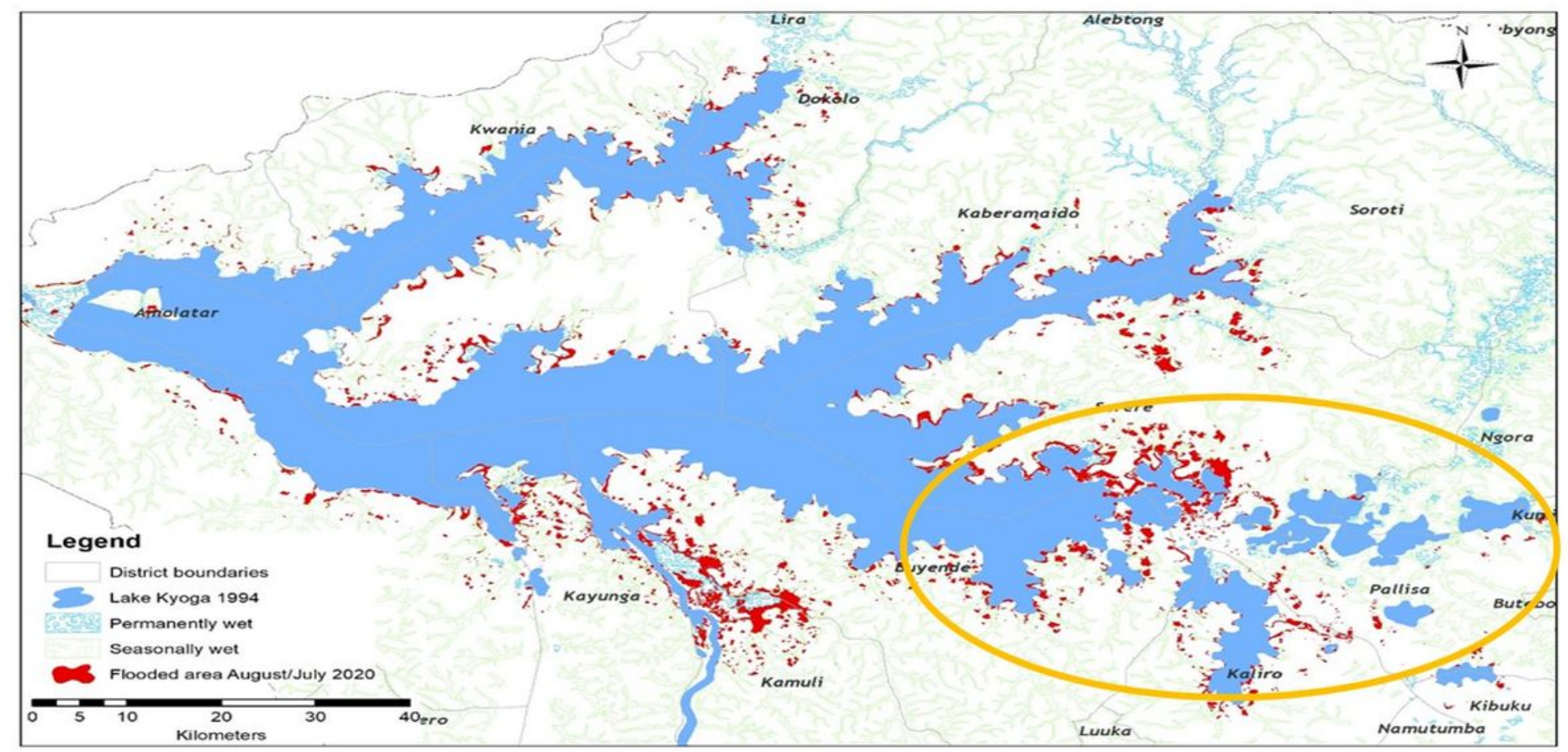

Figure 6

A map showing the extent of 2020 floods in L. Kyoga, the yellow circle shows the study area. Data source (MWE).

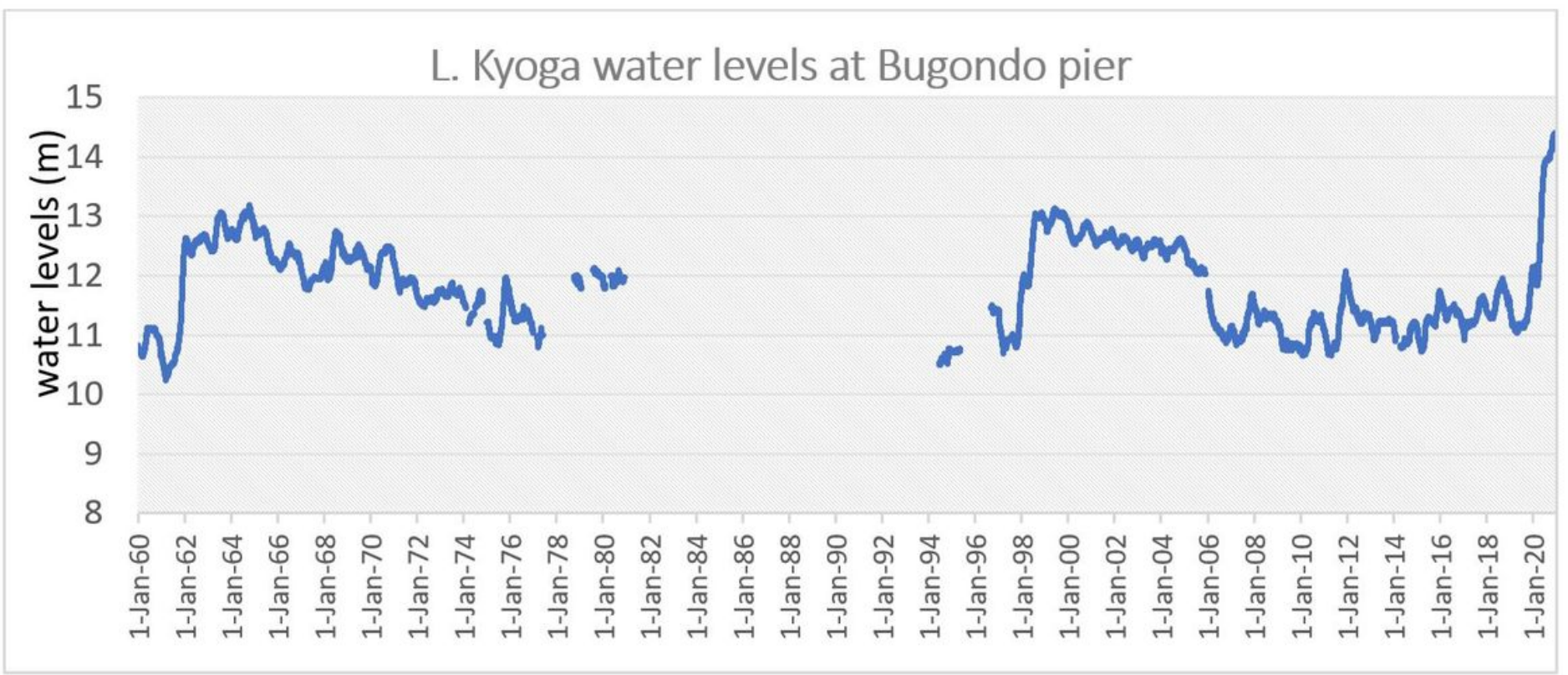

\section{Figure 7}

Water level trends for Lake Kyoga, over six decades. Data source (MWE) 
Page 37/37 